\title{
A clinical-stage cysteine protease inhibitor blocks SARS-CoV-2 infection of human and monkey cells
}

Drake M. Mellott, ${ }^{1}$ Chien-Te Tseng, ${ }^{3}$ Aleksandra Drelich, ${ }^{3}$ Pavla Fajtová, ${ }^{4,5}$ Bala C. Chenna, ${ }^{1}$ Demetrios H. Kostomiris ${ }^{1}$, Jason Hsu, ${ }^{3}$ Jiyun Zhu, ${ }^{1}$ Zane W. Taylor, ${ }^{1,9}$ Klaudia I. Kocurek, ${ }^{2}$ Vivian Tat, ${ }^{3}$ Ardala Katzfuss, ${ }^{1}$ Linfeng Li, ${ }^{1}$ Miriam A. Giardini, ${ }^{4}$ Danielle Skinner, ${ }^{4}$ Ken Hirata, ${ }^{4}$ Michael C. Yoon, ${ }^{4}$ Sungjun Beck $^{4}$, Aaron F. Carlin, ${ }^{8}$ Alex E. Clark ${ }^{4}$, Laura Beretta ${ }^{4}$, Daniel Maneval ${ }^{6}$, Vivian Hook, ${ }^{4}$ Felix Frueh, ${ }^{6}$ Brett L. Hurst, ${ }^{7}$ Hong Wang, ${ }^{7}$ Frank M. Raushel, ${ }^{2}$ Anthony J. O’Donoghue, ${ }^{4}$ Jair Lage de Siqueira-Neto, ${ }^{4}$ Thomas D. Meek ${ }^{1, \#}$, and James H. McKerrow ${ }^{4, \#, *}$

${ }^{1}$ Department of Biochemistry and Biophysics and ${ }^{2}$ Department of Chemistry, Texas A\&M University, 301 Old Main Drive, College Station, Texas 77843, ${ }^{3}$ Department of Microbiology and Immunology, University of Texas, Medical Branch, 3000 University Boulevard, Galveston, Texas, 77755-1001, ${ }^{4}$ Skaggs School of Pharmacy and Pharmaceutical Sciences, University of California San Diego, La Jolla, CA, ${ }^{5}$ Institute of Organic Chemistry and Biochemistry, Academy of Sciences of the Czech Republic, 16610 Prague, Czech Republic, ${ }^{6}$ Selva Therapeutics, ${ }^{7}$ Institute for Antiviral Research, Department of Animal, Dairy, and Veterinary Sciences, 5600 Old Main Hill, Utah State University, Logan, Utah, 84322, ${ }^{8}$ Department of Medicine, Division of Infectious Diseases and Global Public Health, University of California, San Diego, La Jolla, CA 92037, USA. ${ }^{9}$ Current address: Biological Sciences Division, Pacific Northwest National Laboratory, 902 Battelle Blvd, Richland, WA 99353.

* To whom correspondence may be addressed. Email: jmckerrow@health.ucsd.edu

\#Thomas D. Meek and James H. McKerrow are co-Senior Authors.

\section{Contents}

Figures . 
A
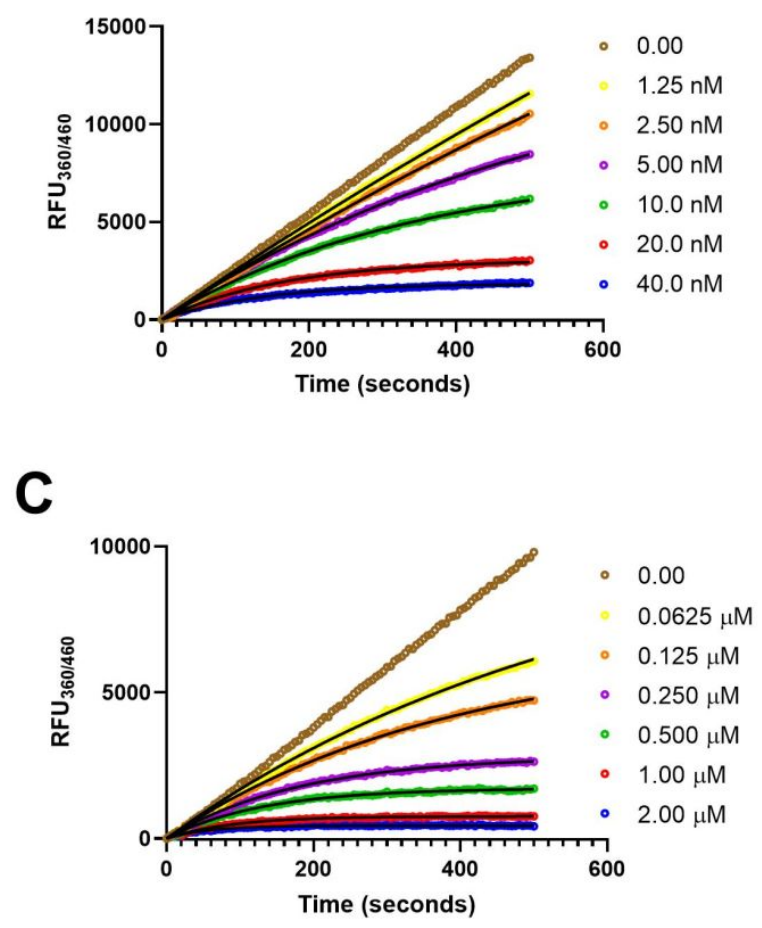

B
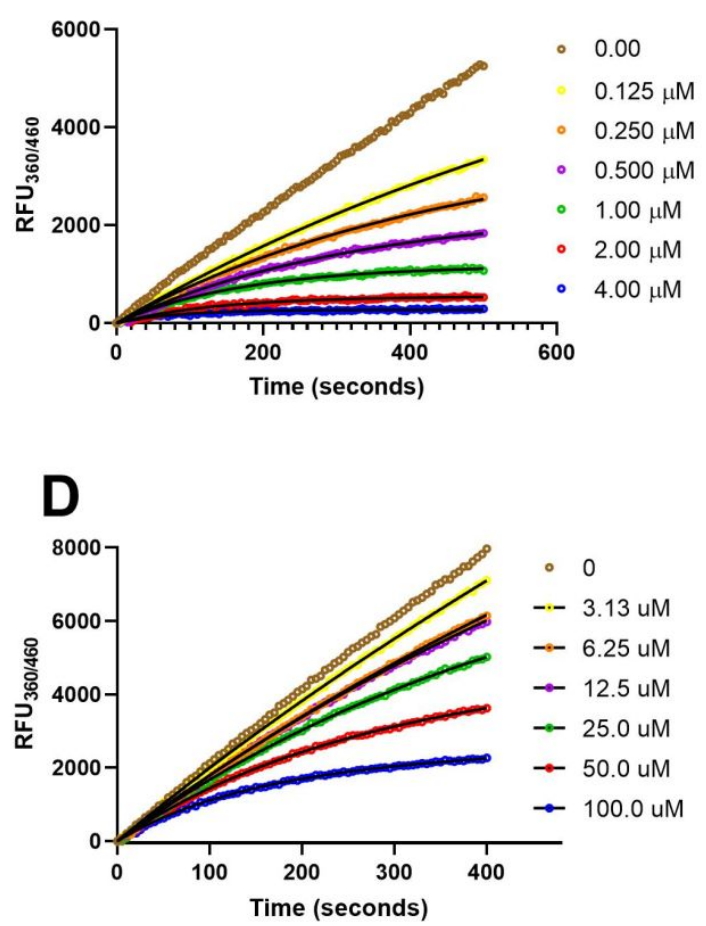

Figure S1. Inactivation of cathepsins with K777 (0-100 $\mu \mathrm{M})$. Cathepsin activity monitored by hydrolysis of dipeptide-AMC substrates. Shown are representative plots of inactivation: A) cathepsin L with Z-Phe-Arg-AMC substrate, B) cathepsin B with Z-Phe-Arg-AMC substrate, C) cathepsin K with Z-Leu-Phe-AMC substrate, D) cathepsin C with $\mathrm{NH}_{2}$-Gly-Phe-AMC substrate. Concentrations of K777 are shown in the figure legends, black lines represent the model of time-dependent inactivation. (eq 1). 
A

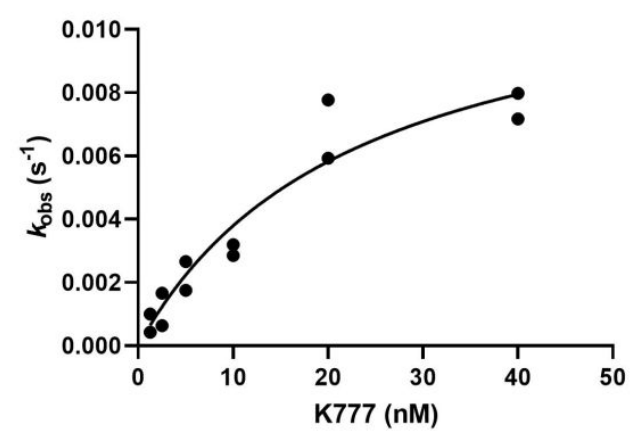

C

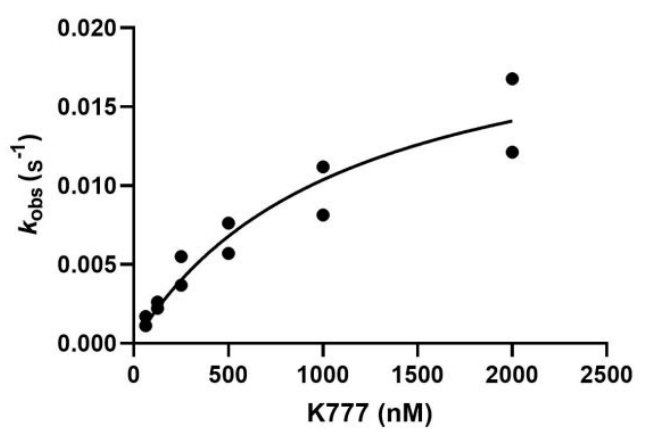

B

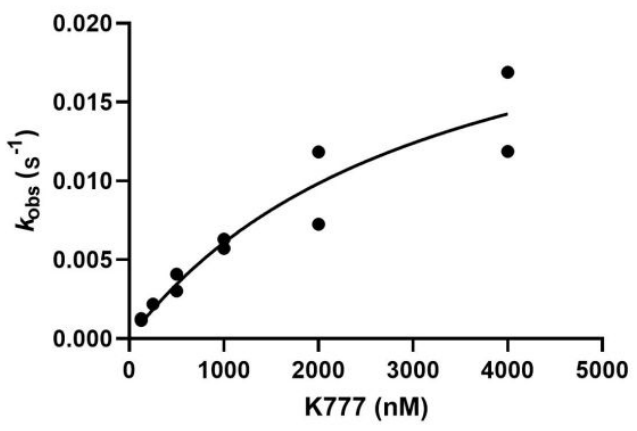

D

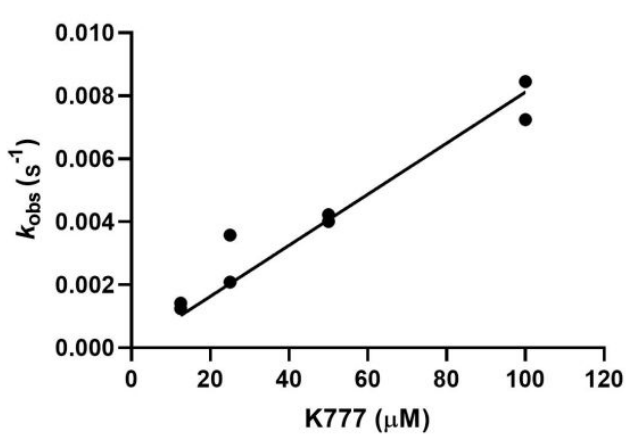

Figure S2. Replot of $\boldsymbol{k}_{\text {inact }}$ values as a function of K777 concentration. Data shown are the individual determinations from replicate experiments shown in S2. For A-C data was fit to eq 3, for $\mathbf{D}$ the data was fit to eq 4 . 

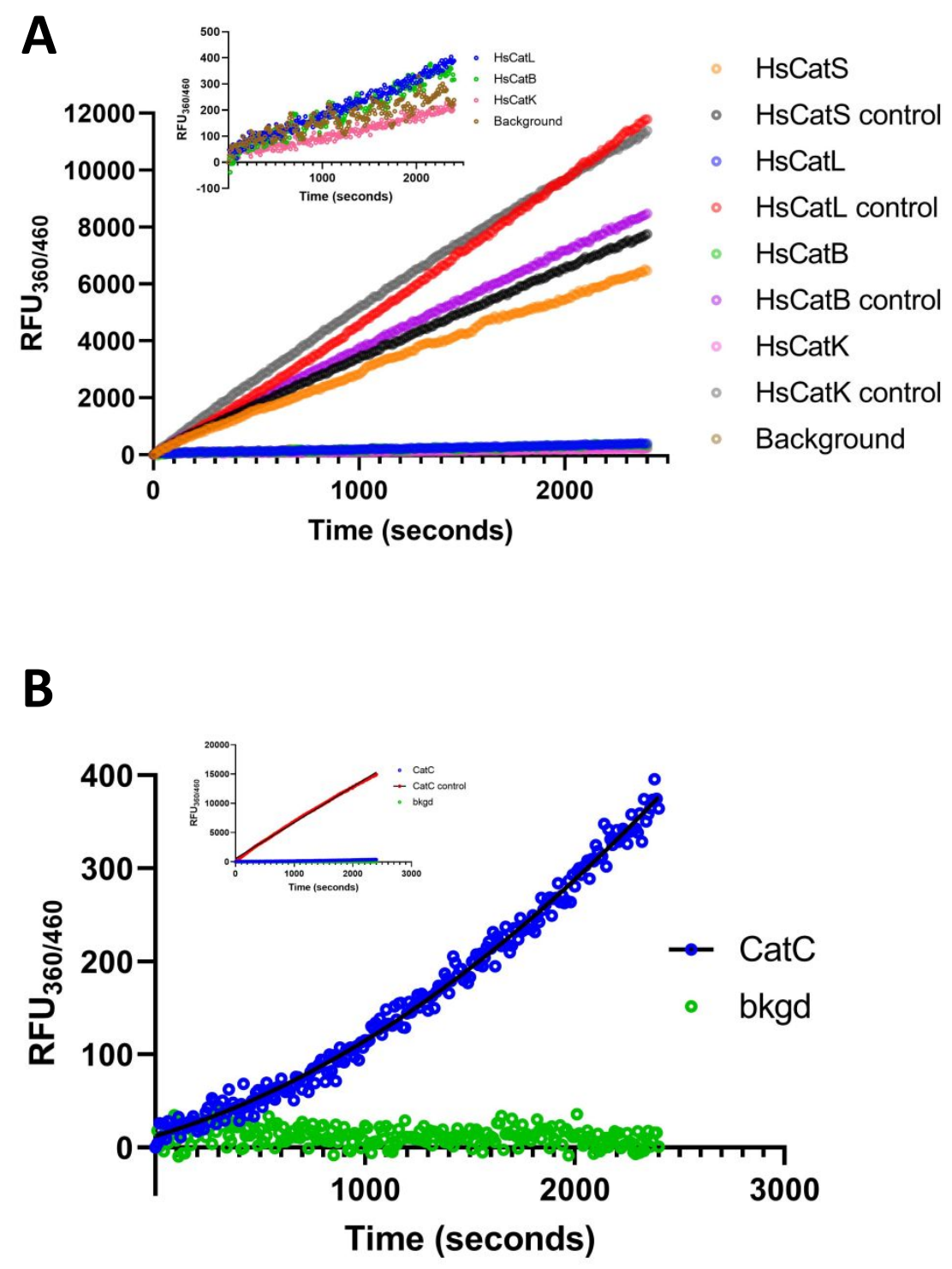

Figure S3. Jump-dilution experiment of inactivated cathepsins. Controls represent enzyme treated with DMSO instead of K777. Background is treated identically to controls except enzyme is replaced with assay buffer. A. Activity of cathepsins B, K, L, and S following incubation with K777. Inset shows rescaling of the $\mathrm{Y}$-axis and omission of the controls. B. Activity of cathepsin $\mathrm{C}$ following incubation with $\mathrm{K} 777$. Inset shows rescaling of the $\mathrm{Y}$-axis and controls. Black line represents model of reactivation, eq 2. 


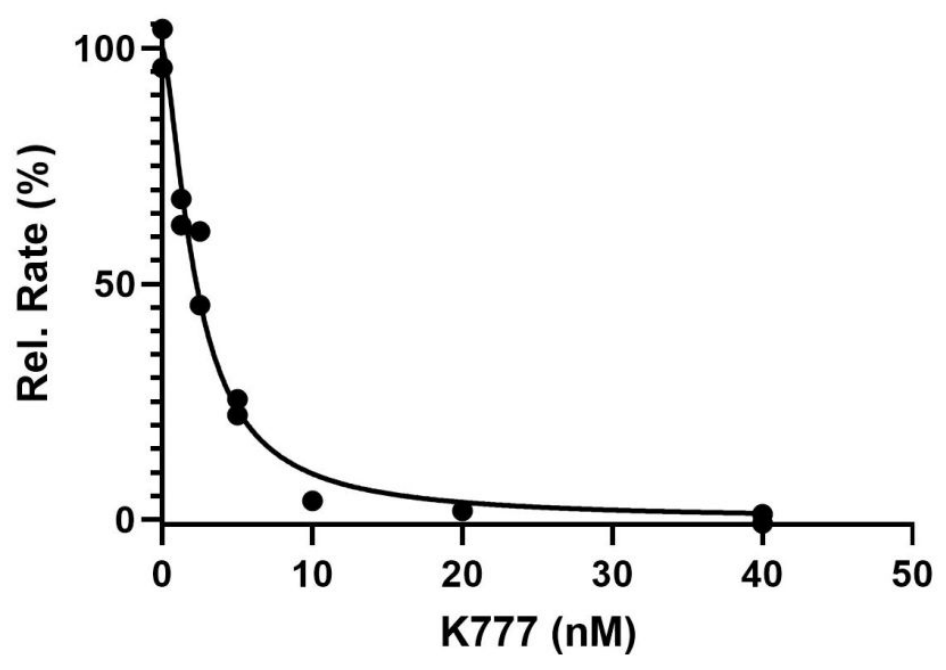

Figure S4. Inhibition of cathepsin S with K777. Inhibition was determined by comparing the steady-state rate at concentrations of K777 (1.25 - $40.0 \mathrm{nM})$ to DMSO control. Data are plotted from two replicate experiments and was fit to eq. 5 
A

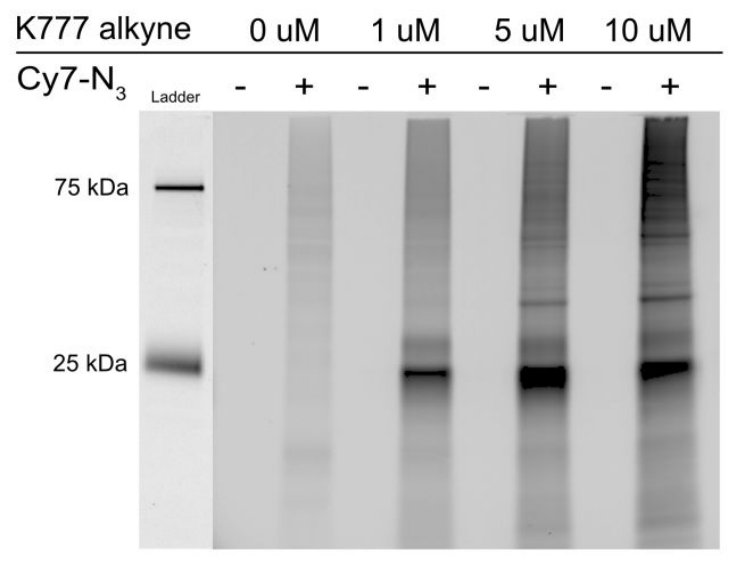

B

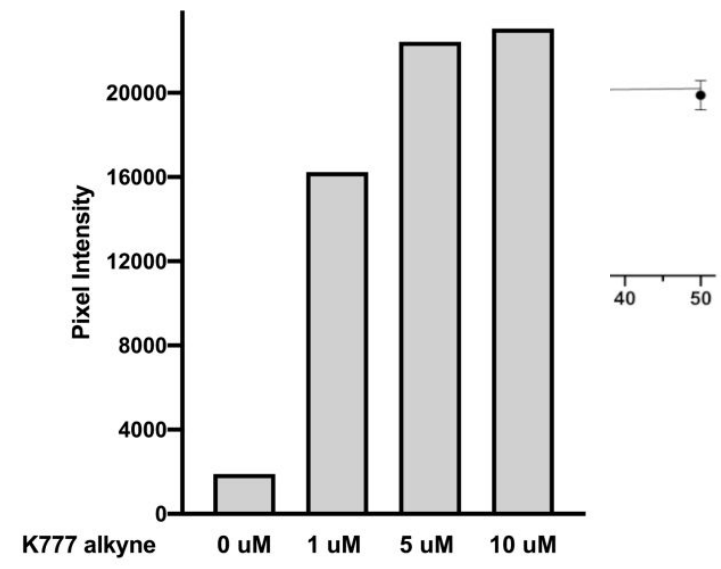

C

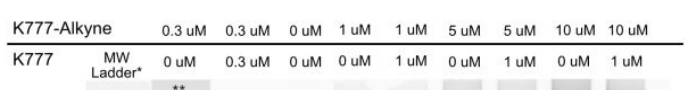

Fi

$75 \mathrm{kDa}$

S 6

$\mathrm{p} \varepsilon$

$\mathrm{d} \epsilon$

$25 \mathrm{kDa}$

G

$\mathrm{m}$

$\mathrm{su}$

* Ladder was imaged at ex/em of 602/650

to show the 25 and $75 \mathrm{kDa}$ protein

** Longer exposure time $(20 \mathrm{sec})$

bz-

stic

tes

eu-

30

the

30

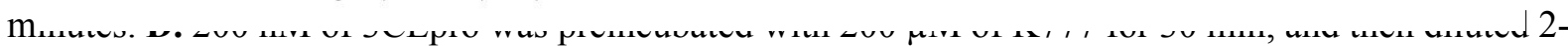

fold Figure S6. A. In gel fluorescence of uninfected Vero E6 cells treated with variable concentrationsf 100 of K777 alkyne followed by labeling with Cy7 azide. B. Densitometry analysis of A. C. In gel 100 fluorescence of un-infected Vero E6 cells treated with varied concentrations of K777 alkyne and ${ }^{3}$ prei1K777.

$\mu \mathrm{M}$

$\mu \mathrm{M}$ Mu-HSSKLQ-AMC. 

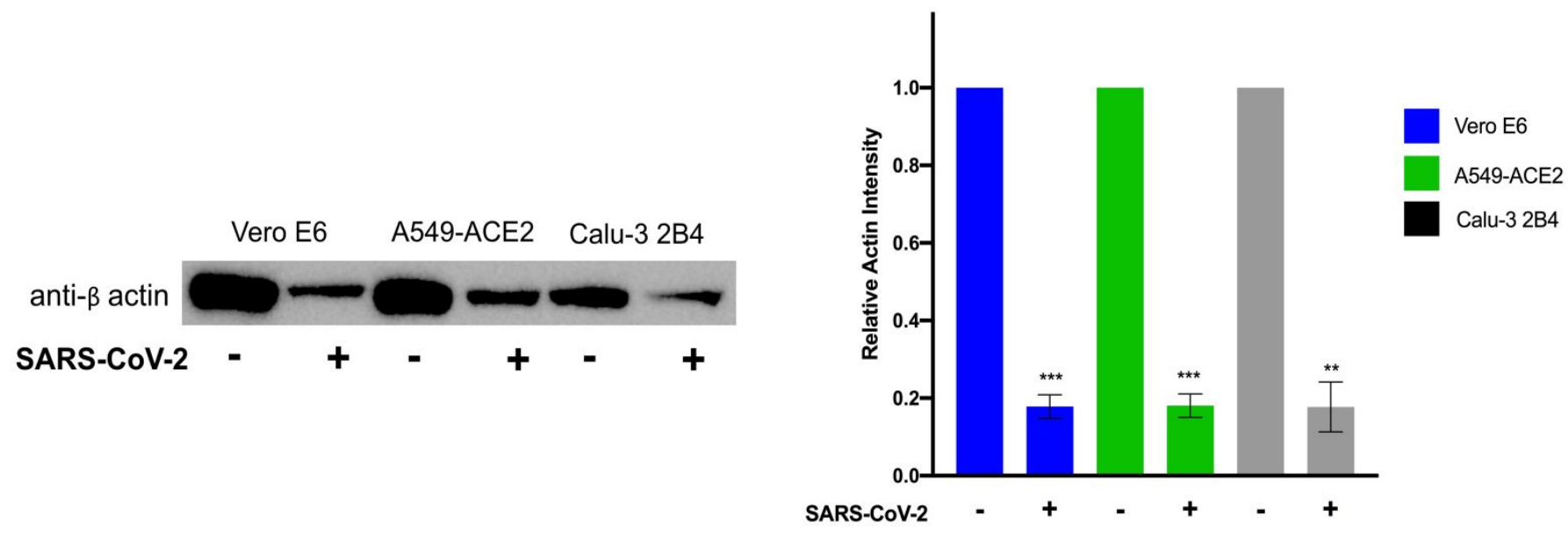

Figure S7. Analysis of actin levels in SARS-CoV-2 infected cell lysates. A. Representative blot of actin levels in virally and non-virally infected cells. B. Densitometry analysis of replicate anti-actin blotting experiments. Signal is normalized to the actin content in cells not infected with SARS-CoV-2. 
A
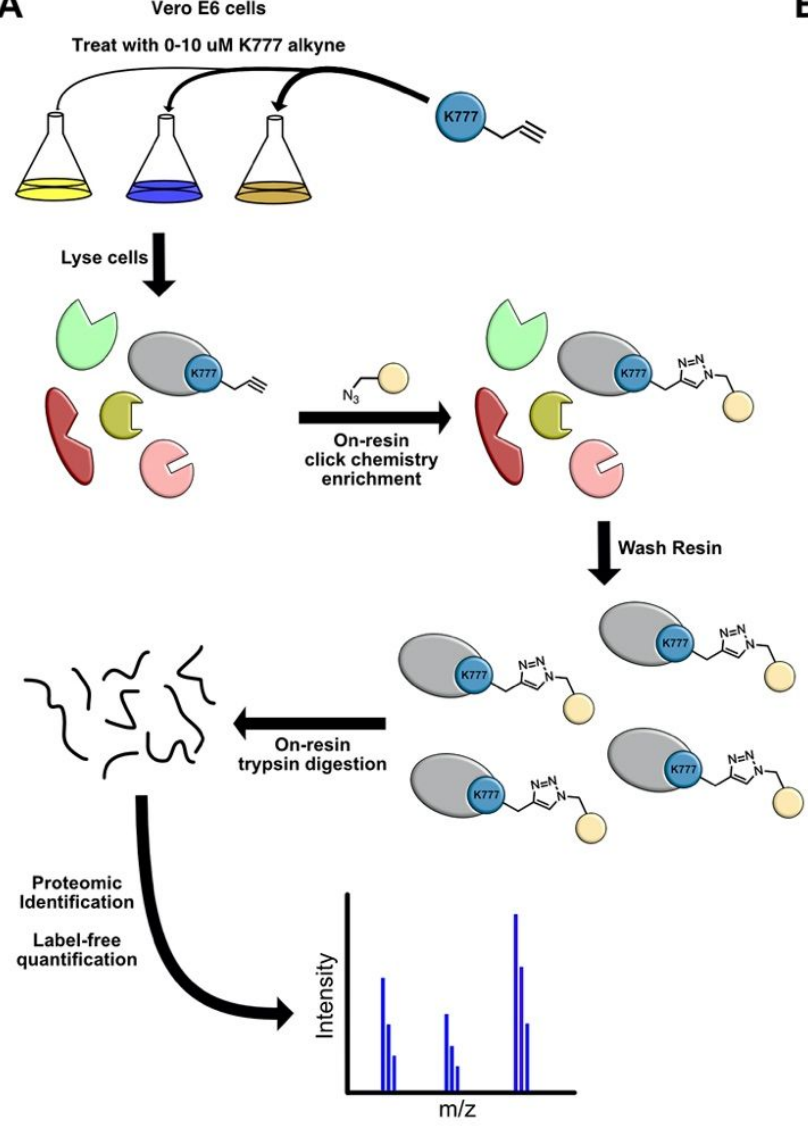

B
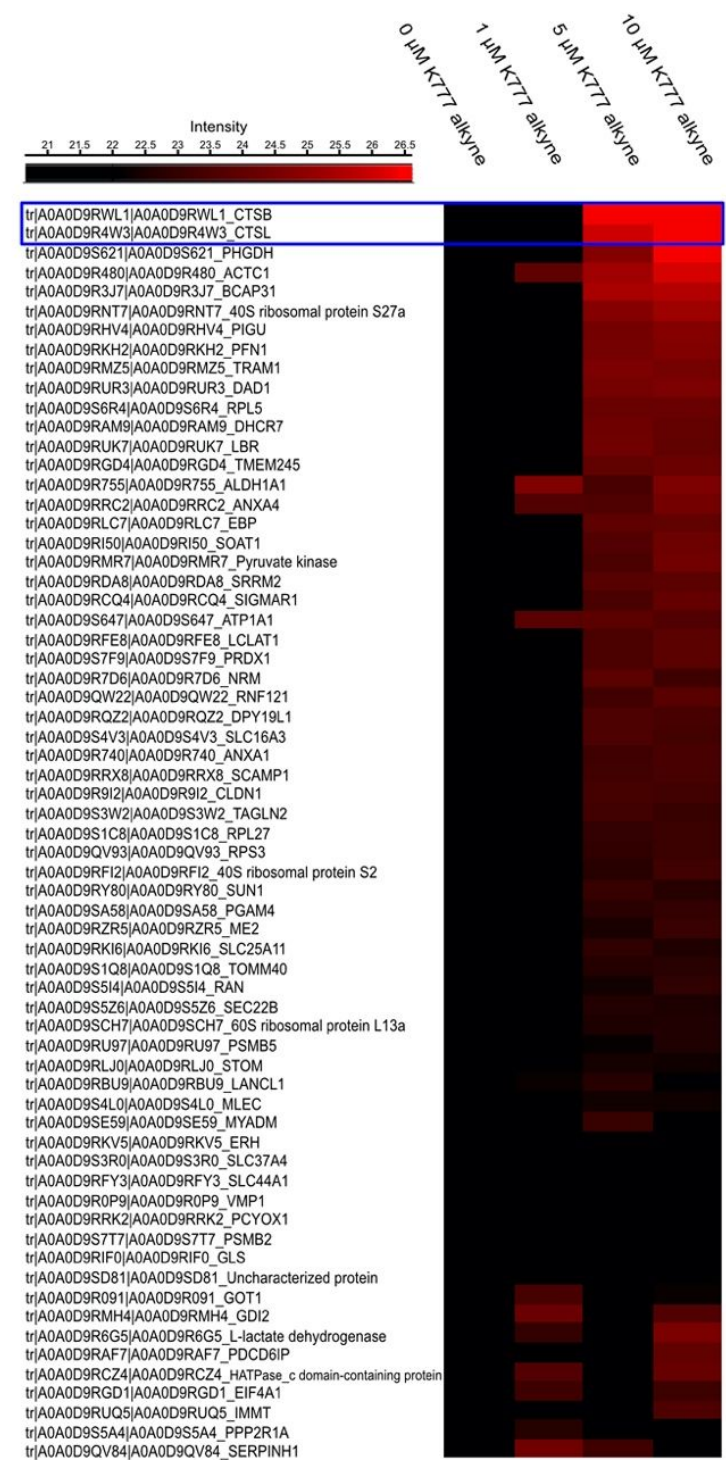

Figure S8. Cathepsins B and L are strongly enriched upon K777 alkyne treatment. A. Schematic of enrichment strategy employed to prepare samples for proteomic processing. B. Heat map of proteomic data clustered from highest to lowest intensity. Intensity reports on the summation of the peptide intensities within a particular protein group. 
A
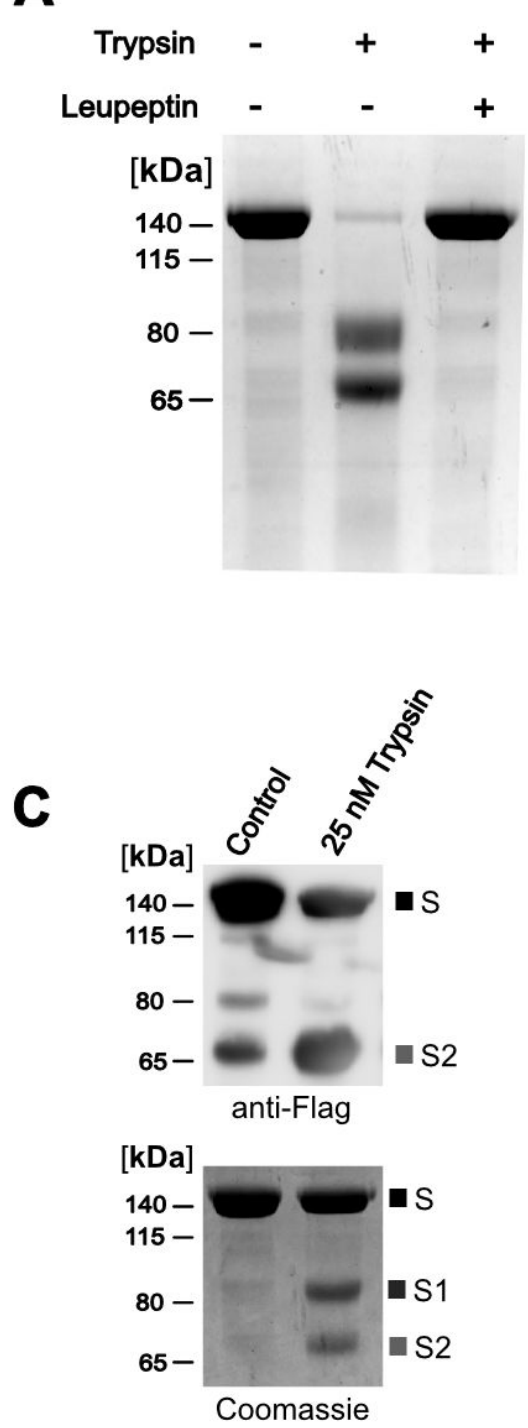

B
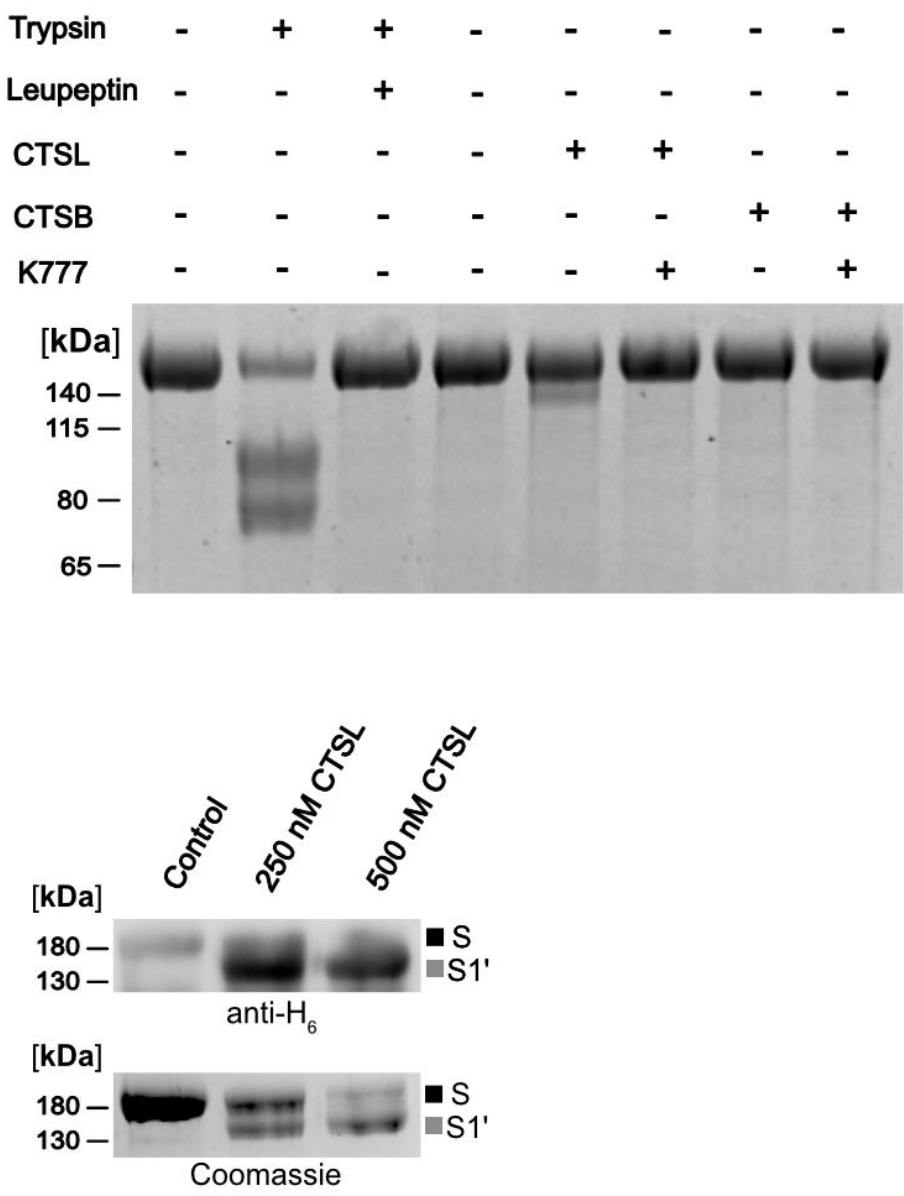

Figure S9. Processing of SARS-CoV-2 spike protein by trypsin, CSTB, and CTSL. A. Trypsin proteolysis of SARS-CoV-2 S produced $\sim 80 \mathrm{kDa}$ and $\sim 65 \mathrm{kDa}$ fragments, which can be blocked by leupeptin. B. Analysis of processing of the trimeric SARS-CoV-2 S protein by trypsin $(25 \mathrm{nM})$, CTSB (250 $\mathrm{nM})$, and CTSL (250 nM) in the presence and absence of inhibitors. C. Representative immunoblotting of trypsin treated SARS-CoV-2 S demonstrates cleavage at the S1/S2 site, which results in a signal for the full length $\mathrm{S}$ protein and a $\sim 65 \mathrm{kDa}$ fragment corresponding to the cleaved S2 domain. D. Immunoblotting of the trimeric SARS-CoV-2 S protein demonstrates that the $\mathrm{S}^{\prime}$ ' product produced contains a C-terminal $\mathrm{H}_{6}$ tag, suggesting that CTSL processing occurred in the S1 domain of the protein. 
A

Human CTSL MNPTLILAAFCLGIASATLTFDHSLEAQWTKWKAMHNRLYGMNEEGWRRAVWEKNMKMIE

Monkey CTSL MNPTFILAALCLGIASATLTFNHSLEAQWTKWKAMHNRLYGMNEEGWRRAVWEKNMKMIE

Human CTSL LHNQEYREGKHSFTMAMNAFGDMTSEEFRQVMNGFQNRKPRKGKVFQEPLFYEAPRSVDW

Monkey CTSL LHNQEYSQGKHSFTMAMNTFGDMTSEEFRQVMNGFQNRKPRKGKVFQEPLFYEAPRSVDW

Human CTSL

REKGYVTPVKNQGQCGSCWAFSATGALEGQMFRKTGRLISLSEQNLVDCSGPQGNEGCNG

Monkey CTSL

REKGYVTPVKNQGQCGSCWAFSATGALEGQMFRKTGKLVSLSEQNLVDCSGPQGNEGCNG

Human CTSL

Human CTSL

Human CTSL

SWGEEWGMGGYVKMAKDRRNHCGIASAASYPTV 333

Monkey CTSL

SWGEEWGMGGYIKMAKDRRNHCGIASAASYPTV 333

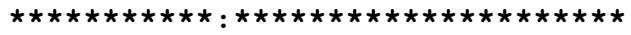

B

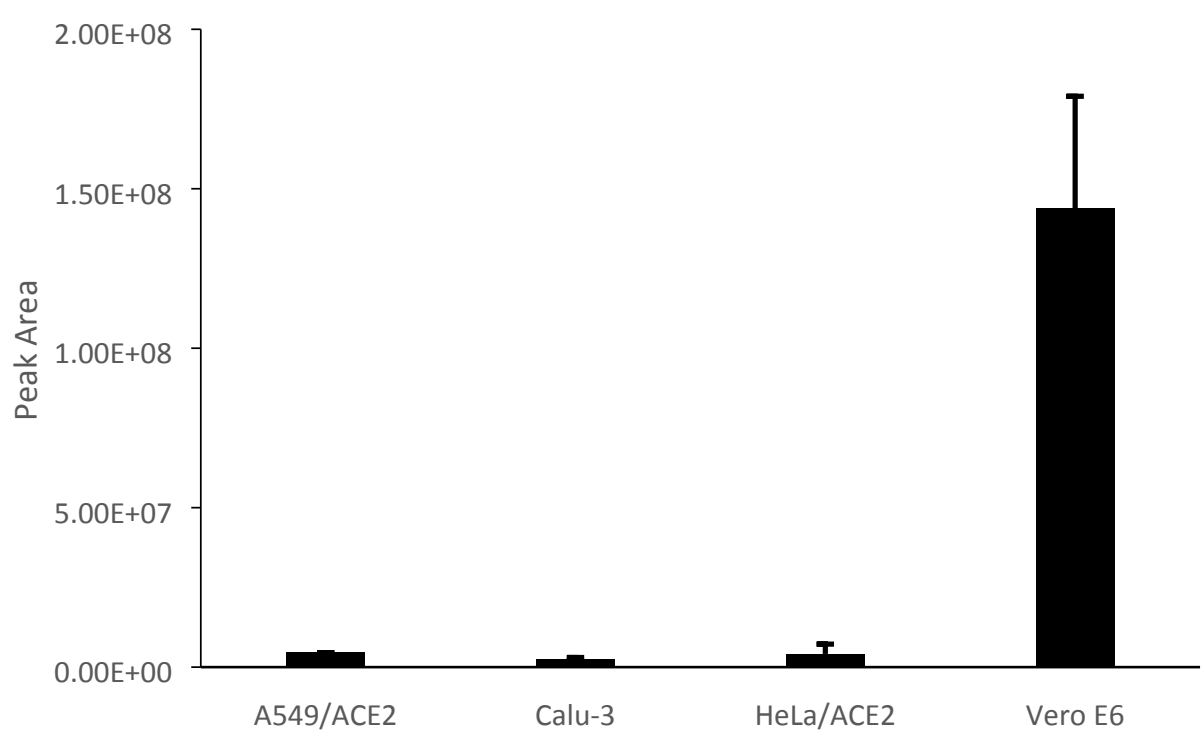

Figure S10. Quantitative proteomics of CTSL. A. Protein alignment of human CTSL and African green monkey CTSL. The C-terminal peptide (NHCGIASAASYPTV) highlight in red font, was found in trypsindigested protein samples from each cell line and therefore used to compare CTSL between cell lines. B Peak area comparison of NHCGIASAASYPTV in four cells lines. 
A. UC San Diego

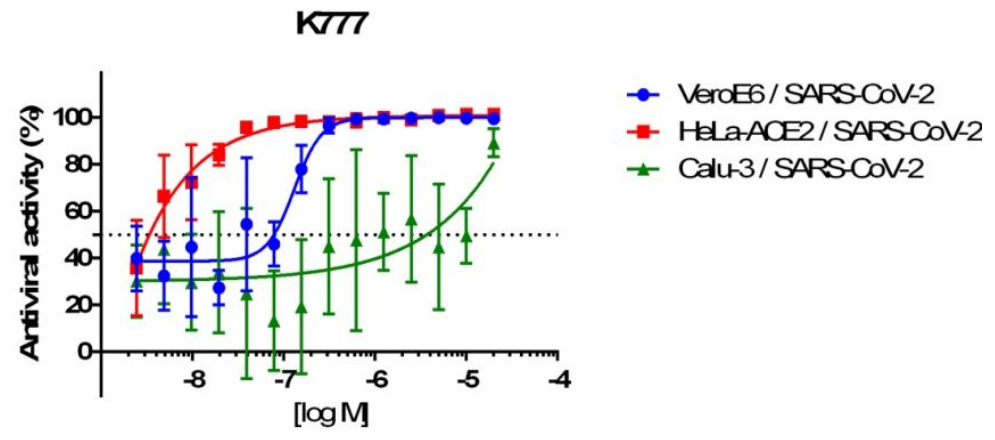

\section{B1. UT Medical Branch}
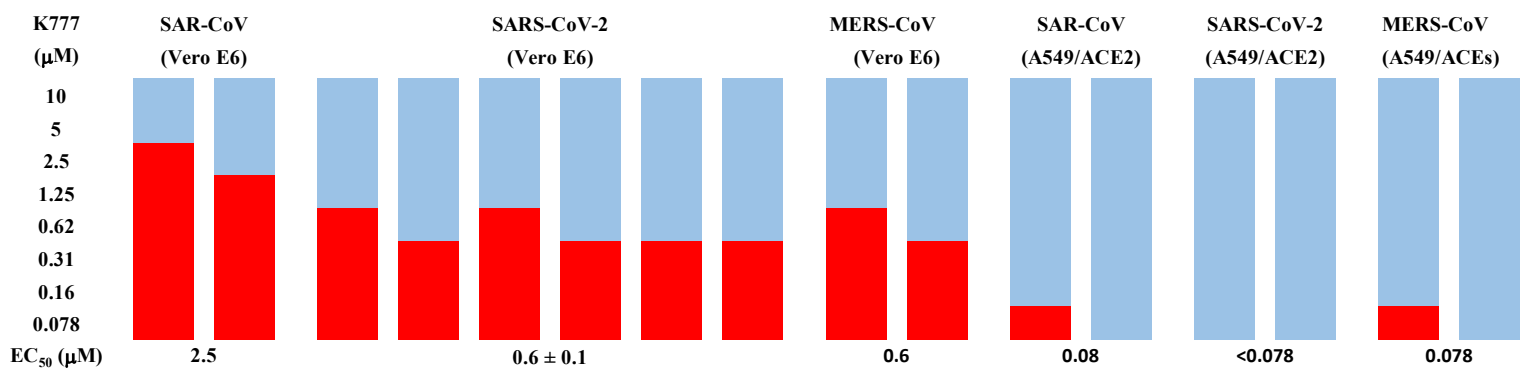

\section{B2. UT Medical Branch}

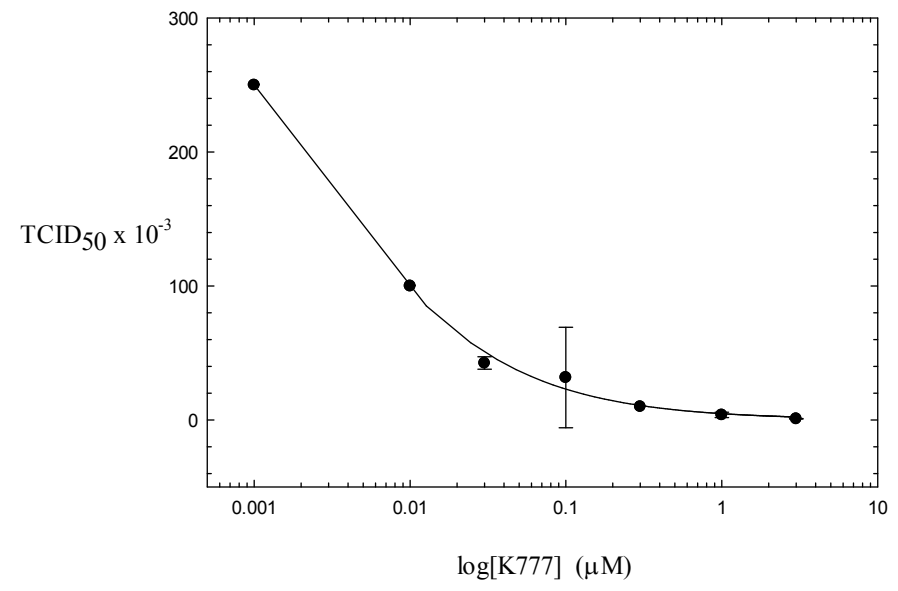

C. Utah State University 


\begin{tabular}{|c|c|c|c|c|c|c|c|c|}
\cline { 2 - 9 } \multicolumn{1}{c|}{} & \multicolumn{4}{c|}{ Vero 76 Cells } & \multicolumn{4}{c|}{ Caco-2 Cells } \\
\hline & Percent Toxicity & \multicolumn{2}{c|}{ Percent CPE } & \multicolumn{2}{c|}{ Percent Toxicity } & \multicolumn{2}{c|}{ Percent CPE* } \\
\hline Conc. & K777 & Remd. & K777 & Remd. & K777 & Remd. & K777 & Remd. \\
\hline $\mathbf{1 0 0}$ & $100.0 \%$ & $60.0 \%$ & $0.0 \%$ & $0.0 \%$ & $95.5 \%$ & $52.0 \%$ & - & - \\
\hline $\mathbf{3 2}$ & $0.0 \%$ & $21.0 \%$ & $0.0 \%$ & $0.0 \%$ & $73.7 \%$ & $32.0 \%$ & - & - \\
\hline $\mathbf{1 0}$ & $0.0 \%$ & $2.0 \%$ & $0.0 \%$ & $0.0 \%$ & $8.2 \%$ & $19.0 \%$ & - & - \\
\hline $\mathbf{3 . 2}$ & $0.0 \%$ & $1.0 \%$ & $0.0 \%$ & $0.0 \%$ & $0.0 \%$ & $3.0 \%$ & - & - \\
\hline $\mathbf{1}$ & $0.0 \%$ & $0.0 \%$ & $0.0 \%$ & $78.0 \%$ & $0.0 \%$ & $0.0 \%$ & - & - \\
\hline $\mathbf{0 . 3 2}$ & $0.0 \%$ & $0.0 \%$ & $0.0 \%$ & $100.0 \%$ & $0.0 \%$ & $0.0 \%$ & - & - \\
\hline $\mathbf{0 . 1}$ & $0.0 \%$ & $0.0 \%$ & $0.0 \%$ & $100.0 \%$ & $0.0 \%$ & $0.0 \%$ & - & - \\
\hline $\mathbf{0 . 0 3 2}$ & $0.0 \%$ & $0.0 \%$ & $100.0 \%$ & $100.0 \%$ & $0.0 \%$ & $0.0 \%$ & - & - \\
\hline
\end{tabular}

K777 tested in $\mu \mathrm{M}$ concentrations.

*No CPE observed in Caco-2 assay. Activity of compound determined by virus yield reduction assay.

Figure S11. Raw data or curves used to calculate $\mathrm{EC}_{50}$ values in Table 1. A. UC San Diego. B. University of Texas Medical Branch: (B1) Concentration-dependence of inhibition of infectivity by K777 in SARSCoV-2-infected cell lines; red samples denote concentrations at which the cytopathic effect (CPE) was observed; and blue samples denote concentrations at which no CPE was observed. B2. Plot of 50\% tissue culture infectious dose $\left(\mathrm{TCID}_{50}\right)$ of Calu-3 $2 \mathrm{~B} 4$ per ml vs. [K777]. Data $(\mathrm{n}=2)$ were fitted to $\mathrm{TCID}_{50}=$ $\min +(\max -\min ) /\left(1+\left([\mathrm{K} 777] / \mathrm{EC}_{50}\right)^{-\mathrm{n}}\right)$ for which $\mathrm{EC}_{50}=0.007 \pm 0.002 \mu \mathrm{M}$. Branch C. Utah State University. Raw data of cellular toxicity of Vero 76 and Caco-2 cells treated with variable concentrations of K777 and remdesivir. Raw data of CPE (Vero 76 cells) and viral yield reduction (Caco-2 cells) of SARS$\mathrm{CoV}-2$ in the presence of variable concentrations of K777 and remdesivir. 
- Cathepsin B - Cathepsin L

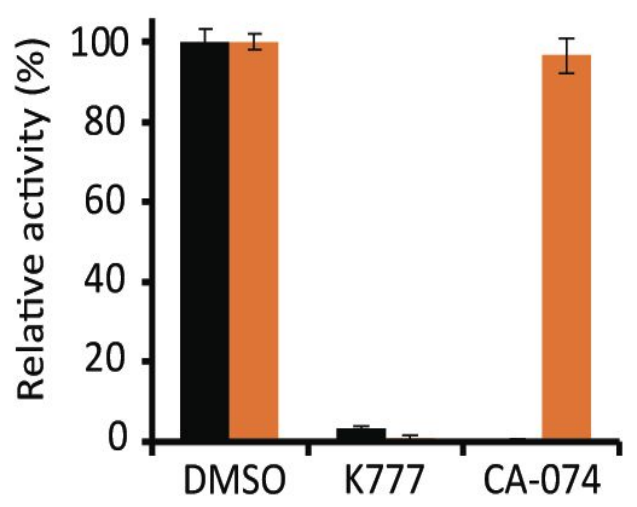

Figure S12. Confirmation that CA-074 $(800 \mathrm{nM})$ is a potent and selective inhibitor of cathepsin B while $\mathrm{K} 777(800 \mathrm{nM})$ inhibits both cathepsin L and B. There is total lack of cathepsin B activity in the presence of CA-074 so no bar is visible. 


\section{Supplementary Methods:}

Expression and purification of 3CLpro-Texas A\&M. All genes and plasmids utilized for the expression of 3CLpro were prepared by Genscript and any subsequent subcloning of these genes was verified by sequencing. All chemical reagents for protein purification were obtained from commercial vendors and used without further purification.

Expression and Purification of 3CL protease-Texas A\&M. Based on the three-dimensional structure of SARS CoV-2 3CLpro (PDB 6Y84.pdb) ${ }^{l}$, we designed expression constructs comprising nucleotides 1005510972 of ORF1AB from GenBank (protein ID QHO62106.1, genome sequence MN988668.1, which encodes 306 amino acids. ${ }^{2}$ This gene was E. coli optimized and ligated into the into the BamHI and XhoI restriction sites of the pGEX-6p1 plasmid (Genscript, USA), resulting in the 3CLpro coding sequence being flanked by an N-terminal GST domain followed by a 3CLpro cleavage sequence (SAVLQ*SGF) and an Cterminal sequence containing a modified PreScission protease sequence (SGVTFQ*GP) preceding a His 6 sequence. ${ }^{3,}{ }^{4}$ Upon expression, auto-proteolysis from 3CLpro removed the N-terminal GST tag, yielding the authentic N-terminus (Ser-Gly-Phe). Purification of the processed protein using immobilized nickel affinity chromatography, followed by treatment with HRV 3C protease then generates 3CLpro with authentic $\mathrm{N}$ and $\mathrm{C}$ termini. This construct was transformed into BL21-DE3 E. coli cells for protein expression and a single colony of the transformed cells was used to inoculate a culture of LB broth containing $100 \mathrm{ug} / \mathrm{mL}$ ampicillin and was incubated at $37^{\circ} \mathrm{C}$ overnight. Subsequently, $1 \mathrm{~L}$ of LB media containing $100 \mathrm{ug} / \mathrm{mL}$ ampicillin was inoculated with the starter culture, and incubated at $37^{\circ} \mathrm{C}$ until reaching O.D. 600 of $0.6-0.8$, at which time expression was induced by the addition of $1 \mathrm{mM}$ isopropyl $\beta$ thiogalactoside (IPTG). The cells were allowed to continue growth at $37^{\circ} \mathrm{C}$ for $4-5 \mathrm{~h}$. and were then harvested by centrifugation $\left(6,300 \mathrm{~g}\right.$ at $\left.4^{\circ} \mathrm{C}\right)$, and either stored at $-80^{\circ} \mathrm{C}$ or lysed immediately for purification. Cells were suspended in $12 \mathrm{mM}$ Tris-HCl, $120 \mathrm{mM} \mathrm{NaCl}, 0.1 \mathrm{mM}$ EDTA, $2 \mathrm{mM}$ DTT, pH: 7.5 (Buffer A). The cell slurry was then lysed using either a French press $(25,000$ psi) or by sonication. Lysates were centrifuged at $26,000 \mathrm{~g}$ to remove cell debris, and clarified lysates were filtered with a 0.45 $\mu \mathrm{m}$ filter. The filtrates were loaded onto a HisTrap HP column (GE Healthcare), and washed with Buffer A. This was directly followed by elution using a linear gradient to $35 \%$ buffer B (12 mM Tris-HCl, 120 $\mathrm{mM} \mathrm{NaCl}, 500 \mathrm{mM}$ imidazole, $0.1 \mathrm{mM}$ EDTA, $2 \mathrm{mM}$ DTT, $\mathrm{pH}$ : 7.5) over 25 column volumes. The fractions containing pure 3 CLpro-PreScision site-His ${ }_{6}$ protein, as determined by SDS-PAGE, were pooled, and the protein concentration was determined using the presumed monomeric molecular weight of $33.9 \mathrm{kDa}$ and an extinction coefficient of $32,800 \mathrm{M}^{-1} \mathrm{~cm}^{-1}$. 3CLpro was twice dialyzed against buffer $\mathrm{A}$ at $4^{\circ} \mathrm{C}$. Proteolysis of the $\mathrm{C}$-terminal $\mathrm{H}_{6}$ tag of the auto processed translated gene product from the pGEX-6p1 plasmid (3CLpro-HRV 3C protease-His ${ }_{6}$ ) was conducted by incubating 3.5 units of Pierce ${ }^{\mathrm{TM}} \mathrm{HRV} 3 \mathrm{C}$ Protease 
(Thermo Fisher Scientific) per mg of 3CLpro overnight at $4^{\circ} \mathrm{C}$ overnight in buffer A. Subsequently, the protein mixture was successively loaded onto a $5 \mathrm{~mL}$ GSTrap HP column and a 5-mL HisTrap HP column (GE Healthcare), to remove the GST-fused HRV 3C protease and undigested $\mathrm{H}_{6}$ tagged protein. The flow through was collected, analyzed by SDS-PAGE, and pure fractions of the tagless 3CLpro were pooled and concentrated (10 kDa molecular weight cutoff filter, GE Healthcare). The protein was deemed to be $\geq 95 \%$ pure by SDS-PAGE, and was stored at $-80^{\circ} \mathrm{C}$ in $12 \mathrm{mM}$ Tris-HCl, $120 \mathrm{mM} \mathrm{NaCl}, 0.1 \mathrm{mM}$ EDTA, $2 \mathrm{mM}$ DTT, (pH 7.5) with 50\% glycerol (v/v). Analytical gel filtration using a Superdex 200 Increase 10/300 GL column (Buffer A at a flow rate of $0.7 \mathrm{~mL} / \mathrm{min}$ ), indicated that native 3CLpro was the expected homodimer.

Recombinant SARS-CoV-2 Mpro protease-UCSD. The SARS-CoV-2 Mpro plasmid was provided by Rolf Hilgenfeld (3) and transformed into E.coli strain BL21-Gold (DE3). General procedures for the expression, purification, and characterization of Mpro protease from SARS-CoV-2 are as described. ${ }^{3}$ Briefly, following $E$. coli culture incubation, cells were lysed by homogenization under native conditions (20 mM Tris-HCl, $150 \mathrm{mM} \mathrm{NaCl}, 0.25$ mM DTT, 5 \% glycerol; $\mathrm{pH}$ 7.8). Insoluble protein was removed by centrifugation at max speed, $20 \mathrm{~min} ., 4^{\circ} \mathrm{C}$. Protein was filtered through a $0.45-\mu \mathrm{M}$ filter . Soluble Mpro was purified by FPLC from the bacterial lysate using $\mathrm{Ni}^{2+}$ chelation chromatography (HisTrap FF column, GE Healthcare Life Sciences) under native conditions (20 mM Tris-HCl, $150 \mathrm{mM} \mathrm{NaCl}, 0.1 \mathrm{mM}$ DTT, 5 $\%$ glycerol; $\mathrm{pH}$ 7.8). The bound Mpro was eluted using a linear gradient of 0-0.5 M imidazole. The active Mpro fractions were pooled and buffer-exchanged into $20 \mathrm{mM}$ Tris- $\mathrm{HCl}, 150 \mathrm{mM} \mathrm{NaCl},<5 \mathrm{mM}$ imidazole, 1 mM DTT, 5 \% glycerol; pH 7.8 using an Amicon Ultracel-10k ultrafiltration device (Millipore), and mixed and incubated with $250 \mathrm{IU}$ of PreScission protease (GenScript) at $4^{\circ} \mathrm{C}$ overnight, resulting in the target protein with authentic N- and C-termini. The PreScission-treated Mpro was loaded on a tandem of GSTTrap FF (GE Healthcare Life Sciences) and HisTrap FF column (GE Healthcare Life Sciences). Active fractions from the flow-through were pooled and stored in $20 \mathrm{mM}$ Tris-HCl, $150 \mathrm{mM} \mathrm{NaCl}, 1 \mathrm{mM}$ DTT, 5 \%. glycerol; $\mathrm{pH}$ 8.0. Purification was monitored by a kinetic assay using the peptidyl fluorogenic substrate, morpholinoureidyl (Mu)-His-Ser-Ser-Lys-Leu-Gln-7-amino-4-methylcoumarin (AMC), and by SDSPAGE. The obtained yield was approximately $6.5 \mathrm{mg}$ of Mpro from $1 \mathrm{~L}$ of culture medium.

Kinetic analysis of SARS-CoV-2 proteases. Recombinant SARS-CoV-2 3CLpro (100 nM) was assayed at $25^{\circ} \mathrm{C}$ in either (a) in $30-\mu \mathrm{L}$ reaction volumes containing $20 \mathrm{mM}$ Tris- $\mathrm{HCl} \mathrm{pH} 7.5,150 \mathrm{mM} \mathrm{NaCl}, 1 \mathrm{mM}$ DTT, $5 \%$ glycerol, 0.01\% Tween 20, $100 \mu \mathrm{M}$ of Mu-HSSKLQ-AMC (Sigma-Aldrich, SCP0224), in 384well black plates in triplicate or (b) in $50-\mu \mathrm{L}$ reaction mixtures containing $20 \mathrm{mM}$ Tris- $\mathrm{HCl} \mathrm{pH} 7.5,150$ $\mathrm{mM} \mathrm{NaCl}$, 0.1 mM EDTA, 2 mM DTT, 10\% DMSO, and 25-50 nM 3CLpro in 96-well plates (Greiner, flat-bottom half volume, clear black plates), using the FRET-based substrate Abz-SAVLQSGFRK(DNP)- 
$\mathrm{NH}_{2}$ wherein peptidolysis was measured at 320/420 nm (ex/em) (Biotek ${ }^{\circledR}$ Synergy M2) in the presence and absence of 0-50 $\mu \mathrm{M}$ K777 in duplicate. Recombinant SARS-CoV-2 PL was assayed in either (a) $50 \mathrm{mM}$ HEPES, $150 \mathrm{mM} \mathrm{NaCl}, 1 \mathrm{mM}$ DTT, 0.01\% Tween 20; pH 6.5 buffer using $50 \mu \mathrm{M}$ Z-RLRGG-AMC (Bachem, I1690) and $24.5 \mathrm{nM}$ enzyme or (b) $50 \mathrm{mM}$ HEPES pH 7.5, $5 \mathrm{mM}$ DTT, $0.1 \mathrm{mg} / \mathrm{mL}$ BSA, 2\% DMSO, $50 \mu \mathrm{M}$ Z-RLRGG-AMC, and $10 \mathrm{nM}$ PLpro, where rates in the presence and absence of K777 were measured at $360 / 460 \mathrm{~nm}$ (ex/em). In some studies, enzymes were pre-incubated with $20 \mu \mathrm{M}$ of $\mathrm{K} 777$ or $0.0025 \%$ DMSO for 15 minutes and then diluted in an equal volume of substrate in assay buffer.

Kinetic analysis of $\mathrm{K} 777$ as an inhibitor of Clan CA cysteine proteases. Assays were conducted at $25^{\circ} \mathrm{C}$ in $50 \mathrm{mM}$ sodium acetate (pH 5.5), $1 \mathrm{mM}$ EDTA, $1 \mathrm{mM}$ CHAPS, 10\% (v/v) DMSO, and $5 \mathrm{mM}$ DTT containing $28 \mathrm{ng} / \mathrm{mL}(\sim 1 \mathrm{nM})$ cathepsin B , 1.1-1.9 ng/mL ( 30-50 pM) cathepsin S, $8.3 \mathrm{ng} / \mathrm{mL}(\sim 320 \mathrm{pM})$ cathepsin K, $25 \mathrm{ng} / \mathrm{mL}(\sim 1 \mathrm{nM})$ cathepsin L, and $3.3 \mu \mathrm{g} / \mathrm{mL}(\sim 132) \mathrm{nM}$ in the presence of 0-0.1 mM K777 and $0.01 \mathrm{mM} \mathrm{Z-FR-AMC}$ for cathepsin S, cathepsin B, and cathepsin L, GF-AMC for cathepsin C, and ZLR-AMC for cathepsin K) 96-well black microplate (Corning Costar®). Rates of peptidolysis of the dipeptide-AMC substrate(s) were measured at either a SpectraMax M5 (Molecular Devices) in or a Synergy HTX (Biotek, Wisnooki, VT) microplate reader with $\lambda_{\mathrm{ex}}=360 \mathrm{~nm}, \lambda_{\mathrm{em}}=460 \mathrm{~nm}$ in $8-60 \mathrm{sec}$ intervals.

To determine the mechanism of inhibition, cathepsin L $(250 \mathrm{ng} / \mathrm{mL})$ or cathepsin $\mathrm{S}(92 \mathrm{ng} / \mathrm{mL})$ was incubated with $10 \mathrm{nM} \mathrm{K777}$, cathepsin B (490 ng/mL) or cathepsin K (97 ng/mL) with $200 \mathrm{nM} \mathrm{K} 777$, and cathepsin $\mathrm{C}(37.3 \mu \mathrm{g} / \mathrm{mL})$ with $100 \mu \mathrm{M} \mathrm{K} 777$ for $1 \mathrm{~h}$ at room temperature, followed by 50 -fold dilution into assay buffer and their residual activity was measured under nearly identical conditions to assay described above.

Fitting of Kinetic Data. For cathepsins that were irreversibly inactivated by K777 the data was fit to:

$$
\text { Product }=\left(\frac{V_{o}}{k}\right)\left(1-e^{-k o b s * t}\right)(\text { eq } 1)
$$

where $\mathrm{V}_{\mathrm{o}}$ is the initial rate, $k_{\text {obs }}$ is the observed rate of inactivation, and $t$ is time.

For cathepsins that were reversibly inactivated by K777 the data were fit to:

$$
\text { Product }=V_{s} t+\left(\frac{V_{o}-V_{s}}{k}\right)\left(1-e^{-k o b s * t}\right)(e q 2)
$$

where $\mathrm{V}_{0}$ and $\mathrm{V}_{\mathrm{s}}$ are respectively the initial and steady-state rates, and $\mathrm{k}_{\mathrm{obs}}$ is the rate constant of conversion of $\mathrm{V}_{0}$ to $\mathrm{V}_{\mathrm{s}}$, and $\mathrm{t}$ is time.

The observed rates of inactivation were then replotted as a function of K777 concentration and fit to: 


$$
k_{\text {obs }}=k_{\text {react }}+\frac{k_{\text {inact }} * I}{\left(K_{I}\left(1+\frac{S}{K_{M}}\right)+I\right)}(\text { eq } 3)
$$

where $k_{\text {inact }}$ is the intrinsic rate of inactivation, $k_{\text {react }}$ is the rate of reactivation, I is the concentration of inhibitor: $\mathrm{K} 777, \mathrm{~K}_{\mathrm{I}}$ is the dissociation constant, $\mathrm{S}$ is the concentration of substrate, and $\mathrm{K}_{\mathrm{M}}$ is the Michaelis constant for the substrate. $\mathrm{K}_{\mathrm{M}}$ was determined for enzyme-substrate pairs by plotting observed catalytic rate versus substrate concentration and fitting the data to the Michaelis-Menten equation (data not published). For irreversible inhibitors, the rate of reactivation is essentially zero (i.e. $k_{\text {react }}=0$ ).

When plots of $k_{\text {obs }}$ vs. [I] were not hyperbolic (lack of saturation with I), the second-order rate constant was approximated from fitting the data to:

$$
\left.k_{\text {obs }}=\left(\frac{k_{\text {inact }}}{K_{I}}\right) I+k_{\text {react }} \text { (eq. } 4\right)
$$

$k_{\text {react }}$ was determined through fitting the results of the jump-dilution experiment to eq.2.

For cases in which inhibition or inactivation was readily reversible, the steady-state rate was plotted against concentration of K777 and fit to:

$$
\text { Rel. Activity }=\frac{100}{1+\left(\frac{{ }^{I} C_{50}}{I}\right)^{H}} \text { (eq. 5) }
$$

where $H$ is the Hill slope.

In gel fluorescence of K777 alkyne treated Vero E6 cells Click Chemistry. Labeling of the K777 alkyne treated cells occurred in a stepwise fashion whereby addition of TBTA in 1:4 DMSO: $n$-butanol (v/v) (100 $\mu \mathrm{M}$ final) was added to $\mathrm{CuSO}_{4}$ in water ( $1 \mathrm{mM}$ final), followed by the addition of $\mathrm{Cy} 7$-azide (Click Chemistry Tools) in DMSO (20 $\mu \mathrm{M}$ final), $24 \mu \mathrm{g}$ cell lysate, and finally sodium ascorbate in water $(2.5 \mathrm{mM}$ final). This reaction was incubated at room temperature for 1.5 hours, and quenched by the addition icecold methanol $(200 \mu \mathrm{L})$, chloroform $(75 \mu \mathrm{L})$, and water $(150 \mu \mathrm{L})$, followed by vortexing and centrifugation at $15,000 \mathrm{xg}$ at $4{ }^{\circ} \mathrm{C}$ for 15 minutes. The top layer of liquid was carefully removed and discarded, and the protein precipitate formed between two liquid phases was not disturbed. An additional $1 \mathrm{~mL}$ of ice-cold methanol was added into the tube, vortexed, and centrifuged at $15,000 \mathrm{xg}$ at $4{ }^{\circ} \mathrm{C}$ for 20 minutes. The supernatant was discarded and this was repeated an additional time. Following removal of the supernatant the protein pellet was allowed to air-dry at room temperature. To the dried pellet 4\% SDS buffer (4\% SDS (w/v), $50 \mathrm{mM}$ TEA, $150 \mathrm{mM} \mathrm{NaCl}$, pH 7.4) was added, and the pellet was sonicated to achieve a clarified 
solution. Then, the solution was added to 4x loading dye (240 mM Tris-HCl, 8\% SDS (w/v), $0.004 \%$ bromophenol blue (to avoid fluorescence from the dye), DTT (5 mM final), and MilliQ water was added to a total volume of $24 \mu \mathrm{L}$. Samples were heated to $95^{\circ} \mathrm{C}$ for 5 minutes, followed by a brief centrifugation at 5,000xg for $1 \mathrm{~min}$. The ladder (Bio-Rad, Precision Plus Protein ${ }^{\mathrm{TM}}$ Dual Color Standards) was diluted 10,000 fold in 4\% SDS buffer and 4x loading dye to avoid strong fluorescence from the ladder during imaging. Samples were analyzed on a 4-12\% Bis-Tris Nu-PAGE gel (Invitrogen). To each well, $20 \mu \mathrm{g}$ of labeled lysate was loaded, and the gel was run at $60 \mathrm{~V}$ for 30 minutes followed by $120 \mathrm{~V}$ for $\sim 90$ minutes. The gels were destained (10\% acetic acid, $40 \%$ methanol, $50 \%$ water) for 1 hour to overnight in the dark followed by imaging the gel on a ChemiDoc imager (Bio-Rad) using the Cy7 blot setting. To visualize the two fluorescent proteins of the protein standard ladder, we used the rhodamine setting. Densitometry of in-gel fluorescence was conducted using ImageJ. The gels were also analyzed by Coomassie Brilliant Blue R-250 staining (Bio-Rad).

Mass Spectrometry for K777-alkyne enrichment analysis. NanoLC-MS/MS analysis was performed using an UltiMate 3000 HPLC system (Thermo Scientific) coupled to a Thermo Scientific Orbitrap Fusion $^{\mathrm{TM}}$ Tribrid $^{\mathrm{TM}}$ mass spectrometer. $1 \mu \mathrm{l}$ of each sample was injected onto a PepMap100 C18 $5 \mu \mathrm{m}$ trap cartridge $(0.3 \times 5 \mathrm{~mm})$ followed by an Acclaim PepMap C18 column $(0.075 \mathrm{~mm} \times 150 \mathrm{~mm}$, particle size 3 $\mu \mathrm{m}$, pore size $100 \AA$ ) at a flow rate of $30 \mu \mathrm{l} / \mathrm{min}$. Peptides were eluted at a flow rate of $0.2 \mu \mathrm{l} / \mathrm{min}$, using $98 \%$ water $/ 2 \%$ acetonitrile with $0.1 \%$ formic acid (A), and $2 \%$ water $/ 98 \%$ acetonitrile with $0.1 \%$ formic acid (B) as mobile phase. The gradient used was as follows: equilibration at $2 \% \mathrm{~B}$ for 5 minutes, ramping up to $45 \%$ at 37 minutes, $90 \% \mathrm{~B}$ at 40 to 46 minutes, ramping down to $2 \% \mathrm{~B}$ at 47 minutes, followed by re-equilibration at $2 \% \mathrm{~B}$ until the end of the run (60 minutes).

Following LC separation, samples were introduced into the mass spectrometer by nanoelectrospray ionization at a spray voltage of $2450 \mathrm{~V}$, with the ion transfer tube temperature set to $275^{\circ} \mathrm{C}$. Data were acquired in top speed mode, with the cycle duration set to 3 seconds. Full scan data were acquired in the Orbitrap in the $400-1600 \mathrm{~m} / \mathrm{z}$ range at a resolution of 120,000 at $\mathrm{m} / \mathrm{z} 200$. MS/MS data were acquired in the ion trap in rapid scan mode, using an isolation window of $1.6 \mathrm{~m} / \mathrm{z}$ with HCD at a fixed normalized collision energy of $28 \%$. Dynamic exclusion was set to 60 seconds.

Data were processed using MaxQuant 1.6.14. Label-free quantification was enabled at the default parameters. The green monkey (Chlorocebus sabaeus) proteome (UniProt ID UP000029965; 19,229 protein sequences) was used as the target database. MaxQuant result files were analyzed using Perseus 1.6.14. Reverse hits, potential contaminant hits, hits only identified by site, and hits for which only one peptide was detected were removed. Only proteins which were not detected in the control samples were considered. Intensity values were logarithmized. Finally, proteins which were detected in at least two test 
samples were hierarchically clustered at default parameters (column clustering was disabled) and plotted as a heat map.

Proteomic analysis of cell line protein extracts. Protein extracts from Vero-E6, HeLa/ACE2, Calu-3 and A549/ACE2 cell lines were prepared by sonication in $50 \mathrm{mM}$ MES, pH 6.0, containing $1 \mathrm{mM}$ EDTA, $1 \mu \mathrm{M}$ pepstatin, $100 \mu \mathrm{M}$ AEBSF and $1 \mathrm{mM}$ DTT in an ice bath. The extracts were clarified by centrifugation $\left(16,000 \mathrm{~g}\right.$ at $4^{\circ} \mathrm{C}$ for $10 \mathrm{~min}$ ), and the protein concentration was determined by BCA assay (Pierce). $100 \mu \mathrm{g}$ of each protein lysate was denatured and reduced with solid urea ( $8 \mathrm{M}$ final) and DTT (5 mM), and incubated at $56^{\circ} \mathrm{C}$ for $30 \mathrm{~min}$. Iodoacetamide was added to each sample (15 mM final) using a freshly-made stock solution, and samples were incubated in the dark at $22^{\circ} \mathrm{C}$ for $30 \mathrm{~min}$. Reactions were quenched with an additional $5 \mathrm{mM}$ DTT, then diluted with $50 \mathrm{mM}$ Tris- $\mathrm{HCl}(\mathrm{pH} 7.5)$ to a final concentration of $1 \mathrm{M}$ urea prior to addition of sequencing-grade trypsin (sequencing grade, Promega V5113, Madison, WI) at 1:50 trypsin/total protein for digestion overnight at $37^{\circ} \mathrm{C}$. Reactions were quenched by adding $10 \%$ TFA to acidify the samples to $\mathrm{pH}<2$, and desalted using $\mathrm{C} 18$ spin columns. Two micrograms of the extracted peptides were analyzed on a Q Exactive mass spectrometer (Thermo) equipped with an Ultimate 3000 HPLC (Thermo). Peptides were separated by reverse phase chromatography on a C18 column $(1.7 \mu \mathrm{m}$ bead size, $75 \mathrm{~mm} \times 20 \mathrm{~cm}$, heated to $65^{\circ} \mathrm{C}$ ) at a flow rate of $300 \mathrm{~nL} / \mathrm{min}$ using a 56-min linear gradient from $4 \%$ B to $17 \%$ B followed by a 20 -min gradient from $17 \%$ B to $25 \%$ B, with solvent A: $0.1 \%$ formic acid (Thermo) in water and solvent B: $0.1 \%$ formic acid in acetonitrile (Thermo). Survey scans were recorded over a $310-1250 \mathrm{~m} / \mathrm{z}$ range at 70,000 resolution at $200 \mathrm{~m} / \mathrm{z}$. MS/MS was performed in data-dependent acquisition mode with HCD fragmentation (28 normalized collision energy) on the 20 most intense precursor ions at 17,500 resolution at $200 \mathrm{~m} / \mathrm{z}$. Data was processed using PEAKS 8.5 (Bioinformatics Solutions Inc.). MS2 data were searched against their proteome (Uniprot). Fixed modifications of carbamidomethylation of cysteines $(57.02146 \mathrm{Da})$, variable modification of acetylation of protein $\mathrm{N}$ termini (42.0106) and oxidation of methionine (15.99492 Da) were specified. A precursor tolerance of $20 \mathrm{ppm}$ and $0.01 \mathrm{Da}$ for MS2 fragments was defined. Data were filtered to $1 \%$ peptide and protein level false discovery rates with the target-decoy strategy.

Statistical analysis. All densitometry and gel quantification analysis was conducted using ImageJ. ${ }^{6}$ For analysis of the statistical significance of the changes in pixel intensity we used an unpaired parametric ttest. P values $\leq 0.05(*), \leq 0.01(* *), \leq 0.001(* * *)$

Western blotting. Texas A\&M University: Cell lysates were prepared as stated above. Samples were separated via SDS-PAGE (Invitrogen) and semi-dry transferred (Bio-Rad) onto an activated PDVF membrane (GE Healthcare Life Sciences) followed by blocking with TBST/5\% wt/vol non-fat milk (1 hr, 
RT). Anti-actin antibody (Sigma Aldrich) or anti-Flag (Cell Signaling Technologies) was added at a $1: 100,000$ or $1: 25,000$ dilution respectively and incubated overnight at $4^{\circ} \mathrm{C}$. The membrane was washed $5 \mathrm{x}$ with TBST, probed with goat-anti rabbit HRP conjugate antibody (1:3000) (Bio-Rad) in TBST/5\% wt/vol non-fat milk (1 h, RT), washed (5x, TBST) followed by addition of ECL substrate (Bio-Rad) and imaged (ChemiDoc, Bio-Rad).

UC San Diego: Protein extracts from Vero-E6, HeLa/ACE2, Calu-3 and A549/ACE2 cell lines were prepared by sonication in $50 \mathrm{mM}$ MES (pH 6.0) containing $1 \mathrm{mM}$ EDTA, $1 \mu \mathrm{M}$ pepstatin, $100 \mu \mathrm{M}$ AEBSF and $1 \mathrm{mM}$ DTT in an ice bath. The extracts were clarified by centrifugation $\left(16,000 \mathrm{~g}\right.$ at $4{ }^{\circ} \mathrm{C}$ for $\left.10 \mathrm{~min}\right)$, and the protein concentration was determined by BCA assay (Pierce). $10 \mu \mathrm{g}$ of protein were resolved by SDS-PAGE (15\% polyacrylamide gel) under reducing conditions, transferred to a PVDF membrane, and blocked for $16 \mathrm{~h}$ in 10\% non-fat milk in TBST. The membrane was then washed $3 \mathrm{x}$ in TBST, incubated for $1 \mathrm{~h}$ with anti-CatL polyclonal IgG (R\&D Systems, AF952-SP) diluted 1:1,000 in TBST, followed by 30 min incubation with rabbit anti-goat HRP IgG (SouthernBiotech, \#6164-05) at a dilution of 1:2,000. After washing in TBST, the membrane was developed with Immobilon Crescendo Western HRP substrate (MilliporeSigma), and imaged using an ChemiDoc Imaging System (Biorad).

\section{Synthetic Chemistry: Synthesis and Characterization of 3CLpro peptide substrate and K777:}

General synthetic considerations. The reagents and starting materials used were obtained from commercial vendors and used as received without any purification. Reactions were carried in an inert atmosphere of nitrogen unless otherwise specified. Progress of the reactions were monitored using Thin Layer Chromatography (TLC) and LC-MS analysis, by employing an HPLC-MS (UltiMate 3000 equipped with a diode array coupled to a MSQ Plus Single Quadrupole Mass Spectrometer, ThermoFisher Scientific) using electrospray positive and negative ionization detectors. HPLC conditions used: column: Phenomenex Luna $5 \mu \mathrm{m} \mathrm{C18(2)} 100 \AA$, $4.6 \mathrm{~mm}, 50 \mathrm{~mm}$, Mobile phase A: water with $0.1 \%$ formic acid (v/v). Mobile phase B: $\mathrm{MeCN}$ with $0.1 \%$ formic acid (v/v). Temperature: $25^{\circ} \mathrm{C}$. Gradient: $0-100 \%$ B over 6 min, then a 2 min hold at 100\% B. Flow: $1 \mathrm{~mL} / \mathrm{min}$. Detection: MS and UV at 254, 280, 214, and $350 \mathrm{~nm} .{ }^{1} \mathrm{H} /{ }^{13} \mathrm{C} \mathrm{NMR}$ spectra were obtained in $\mathrm{CDCl}_{3}, \mathrm{CD}_{3} \mathrm{OD}$, or DMSO- $d_{6}$ at $400 \mathrm{MHz} / 100 \mathrm{MHz}$ at $298 \mathrm{~K}$ on a Bruker Avance III NanoBay console with an Ascend magnet. The following abbreviations were utilized to describe peak patterns when appropriate: $\mathrm{br}=$ broad, $\mathrm{s}=$ singlet, $\mathrm{d}=$ doublet, $\mathrm{q}=$ quartet, $\mathrm{t}=$ triplet, and $\mathrm{m}=$ multiplet. The final compounds used for testing in assays and biological studies had purities that were determined to be $>95 \%$ as evaluated by their proton NMR spectra and/or their HPLC/MS traces based on ultraviolet detection at $254 \mathrm{~nm}$ (K777 and K777 alkyne) or $350 \mathrm{~nm}$ (Abz FRET peptide). All reagents and starting materials were obtained from commercial suppliers, and used without further purification unless otherwise 
stated. Solution phase reactions were conducted under an atmosphere of nitrogen at ambient temperature unless otherwise noted. Reaction progress was monitored using thin-layer chromatography and by HPLCMS (UltiMate 3000 equipped with a diode array coupled to an ISQ EM single quadrupole mass spectrometer, Thermo Fisher Scientific) using electrospray positive and negative ionization detectors. Reported liquid chromatography retention times $\left(t_{\mathrm{R}}\right)$ were established using the following conditions: column: Phenomenex Luna $5 \mu \mathrm{m} \mathrm{C18(2)} 100 \AA \AA, 4.6 \mathrm{~mm}, 50 \mathrm{~mm}$; mobile phase A: water with $0.1 \%$ formic acid (v/v); mobile phase B: $\mathrm{MeCN}$ with $0.1 \%$ formic acid (v/v); temperature: $25^{\circ} \mathrm{C}$; gradient: $0-100 \% \mathrm{~B}$ over $6 \mathrm{~min}$, then a $2 \mathrm{~min}$ hold at $100 \% \mathrm{~B}$; flow: $1 \mathrm{~mL} \mathrm{~min}^{-1}$; and detection: MS and UV at 254, 280, 214, and $350 \mathrm{~nm}$. Semi-preparative HPLC purification of compounds was performed on a Thermo Fisher Scientific UltiMate 3000 with a single wavelength detector coupled to a fraction collector. Purifications were conducted using the following conditions: column: Phenomenex Luna $5 \mu \mathrm{m}$ C18(2) $100 \AA, 21.2 \mathrm{~mm}$, $250 \mathrm{~mm}$; mobile phase A: water with $0.1 \%$ formic acid (v/v); mobile phase B: acetonitrile with $0.1 \%$ formic acid $(\mathrm{v} / \mathrm{v})$; temperature: room temperature.

Fmoc-Lys(DNP)-OH. A round bottom flask charged with Fmoc-Lys-OH (2 g, 5.43 mmol) was purged with $\mathrm{N}_{2}$ gas to yield positive pressure, followed by the addition of $50 \mathrm{~mL}$ anhydrous dichloromethane. Subsequently, DIPEA (2.84 mL, $16.3 \mathrm{mmol})$ was added, followed by the dropwise addition of 1-fluoro2,4-dinitrobenzene $(700 \mu \mathrm{L}, 5.54 \mathrm{mmol})$. The mixture was allowed to react for 3.5 hours at which time the reaction mixture was washed with $1 \mathrm{~N} \mathrm{HCl}$ (1 time), water (3 times), brine (1 time), dried over $\mathrm{Na}_{2} \mathrm{SO}_{4}$, and concentrated under reduced pressure. The crude product was subjected to flash purification on silica (2\% $\mathrm{MeOH}: \mathrm{DCM}$ ), which following concentration under reduced pressure yielded a bright yellow fluffy powder $\left(1.89 \mathrm{~g}, 65.2 \%\right.$ yield). LC-MS $t_{\mathrm{R}}: 5.99 \mathrm{~min}, \mathrm{~m} / \mathrm{z} 535.12$ [M+1H], $\mathrm{C}_{27} \mathrm{H}_{26} \mathrm{~N}_{4} \mathrm{O}_{8}$ Calcd. $535.18[\mathrm{M}+1 \mathrm{H}]$.

Boc-2-Abz-OH. A round bottom flask charged with 2-aminobenzoic acid (2 g, 14.58 mmoles) was dissolved in $20 \mathrm{~mL}$ of water and the $\mathrm{pH}$ was adjusted to 8 by adding $10 \mathrm{~N} \mathrm{NaOH}$ dropwise. Subsequently, di-tert-butyl dicarbonate $(3.5 \mathrm{~g}, 16.04 \mathrm{mmol})$ was dissolved in $20 \mathrm{~mL}$ of anhydrous THF was added dropwise to the reaction which was allowed to proceed overnight. The organic layer was removed under reduced pressure, and the aqueous layer was acidified with 2N HCL and extracted with ethyl acetate 3 times. The organic layer was washed with water ( 2 times), and brine ( 2 times), and dried over anhydrous sodium sulfate, and removed under reduced pressure yielding an off-white powder. (2.76 g, 80.7\% yield) LC-MS $t_{\mathrm{R}}: 5.36 \mathrm{~min}, \mathrm{~m} / \mathrm{z} 236.08$ [M-1H], $\mathrm{C}_{12} \mathrm{H}_{15} \mathrm{NO}_{4}$ Calcd. 236.10 [M-1H].

Fmoc-SAVLQSGFRK(DNP)-NH $\mathbf{N}_{2}$. To a syringe fitted with a frit, 200 umol of Rink Amide AM resin (Novabiochem, $0.73 \mathrm{mmol} / \mathrm{g}$ ) was washed with dichloromethane (DCM), and swelled in N,N- 
dimethylformamide (DMF). The Fmoc resin was deprotected using 20\% piperidine in DMF (v/v) for 15 minutes (3 times), followed by five washes with DMF. Coupling of Fmoc-Lys(DNP)-OH was conducted using 3-fold excess of the amino acid versus resin loading (0.6 mmol), (1-cyano-2-ethoxy-2oxoethylidenaminooxy)dimethylamino-morpholino-carbenium hexafluorophosphate (COMU) (0.6 mmol), and DIPEA (1.2 mmol) under agitation for 3 hours (2 times). Washing of the resin with DMF, followed by ninhydrin analysis verified the coupling was complete. The resin was then capped by 45 minutes of agitation with $25 \%$ acetic anhydride in DMF (v/v) and DIEA (0.3 mmol), followed by DMF washes (5 times). Subsequent synthesis of the peptide occurred in a stepwise fashion: deprotection of the Fmoc protecting group by $20 \%$ piperidine in DMF (v/v) for 15 minutes (2 times), DMF wash ( 5 times), ninhydrin analysis, addition of Fmoc-AA-OH (0.6 mmol), COMU (0.6 mmol), and DIEA (1.2 mmol) (allowed to pre-activate for 2 minutes prior to addition to resin) and coupling for 1 hour, washing of the resin with DMF (5 times), ninhydrin analysis, capping of unreacted amine groups with $25 \%$ acetic anhydride in DMF (v/v) and DIPEA ( $0.3 \mathrm{mmol})$ for 15 minutes, and washing of the resin with DMF (5 times). All steps were carried out under constant agitation. Test cleavage of the peptide was conducted using $\sim 5-10 \mathrm{mg}$ of resin suspended in hexafluoroisopropanol (HFIP) containing $0.5 \mathrm{~N} \mathrm{HCl}$ (aq), $5 \% \mathrm{v} / \mathrm{v}$ water, and $2.5 \% \mathrm{v} / \mathrm{v}$ triisopropylsilane for two hours. The solution was then removed under a stream of $\mathrm{N}_{2}$ gas, and the resulting material was dissolved in acetonitrile, filtered, and analyzed by LC-MS, showing that the peptide was the major product $(\mathrm{m} / \mathrm{z} 740.4[\mathrm{M}+2 \mathrm{H}] ; 1479.7[\mathrm{M}+1 \mathrm{H}]$ or $740.4[\mathrm{M}+2 \mathrm{H}]$ calcd.). The peptide-laden resin was then washed with DCM (3 times), dried under vacuum, and stored in a desiccator for further synthesis.

Abz-SAVLQSGFRK(DNP)-NH2. To a syringe fitted with a frit, half of dry resin bound Fmoc-(DNP)Rink Amide peptide was suspended in DMF for 20 minutes. Treatment with 20\% piperidine in DMF (v/v) for 15 minutes ( 3 times), followed by DMF washes ( 5 times) and a ninhydrin test confirmed removal of the Fmoc group. To the free amine, Boc-2-Abz-OH (0.3 mmol), COMU (0.3 mmol), and DIPEA (0.6 mmol) (allowed to pre-activate for 2 minutes) was added and allowed to couple overnight. The resin was washed with DMF (5 times), and the coupling was repeated for another four hours to enhance the yield. The resin was then washed with DMF (5 times), DCM (3 times), and MeOH (3 times). Subsequent cleavage of the peptide with HFIP containing $0.5 \mathrm{~N} \mathrm{HCl}(\mathrm{aq}), 5 \% \mathrm{v} / \mathrm{v}$ water, and $2.5 \% \mathrm{v} / \mathrm{v}$ triisopropylsilane for four hours ( 2 times) was followed by removal of the solution via rotary evaporation, precipitation of the peptide in ice cold diethyl ether. The crude mixture was solubilized in a small volume of DMF, and subjected to semipreparative HPLC (5\%-52\% B over 20 mins, then 52-100\% B to 26 minutes, and 100\% B until 29 minutes at $21.2 \mathrm{ml} / \mathrm{min}$ ). The fractions containing pure peptide ( $\geq 95 \%$ pure) were then lyophilized to yield a fluffy yellow powder (42.4 mg, 29.2\% yield as a formic acid salt) LC-MS $t_{\mathrm{R}}: 5.36 \mathrm{~min}, \mathrm{~m} / \mathrm{z} 688.89$ [M+2H], $459.79[\mathrm{M}+3 \mathrm{H}], \mathrm{C}_{61} \mathrm{H}_{89} \mathrm{~N}_{19} \mathrm{O}_{18}$ Calcd $1376.66[\mathrm{M}+1 \mathrm{H}], 688.83[\mathrm{M}+2 \mathrm{H}], 459.56[\mathrm{M}+3 \mathrm{H}]$. 


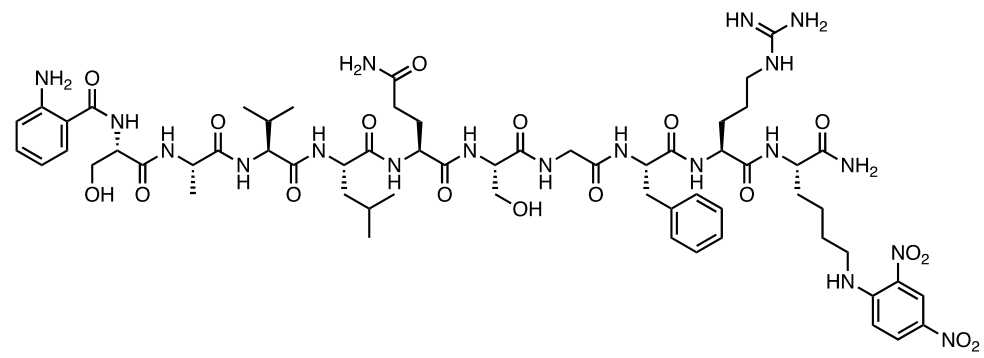

Abz-SAVLQSGFRK(DNP)-NH

Synthetic Schemes for K777 and K777 alkyne ${ }^{a}$ : 


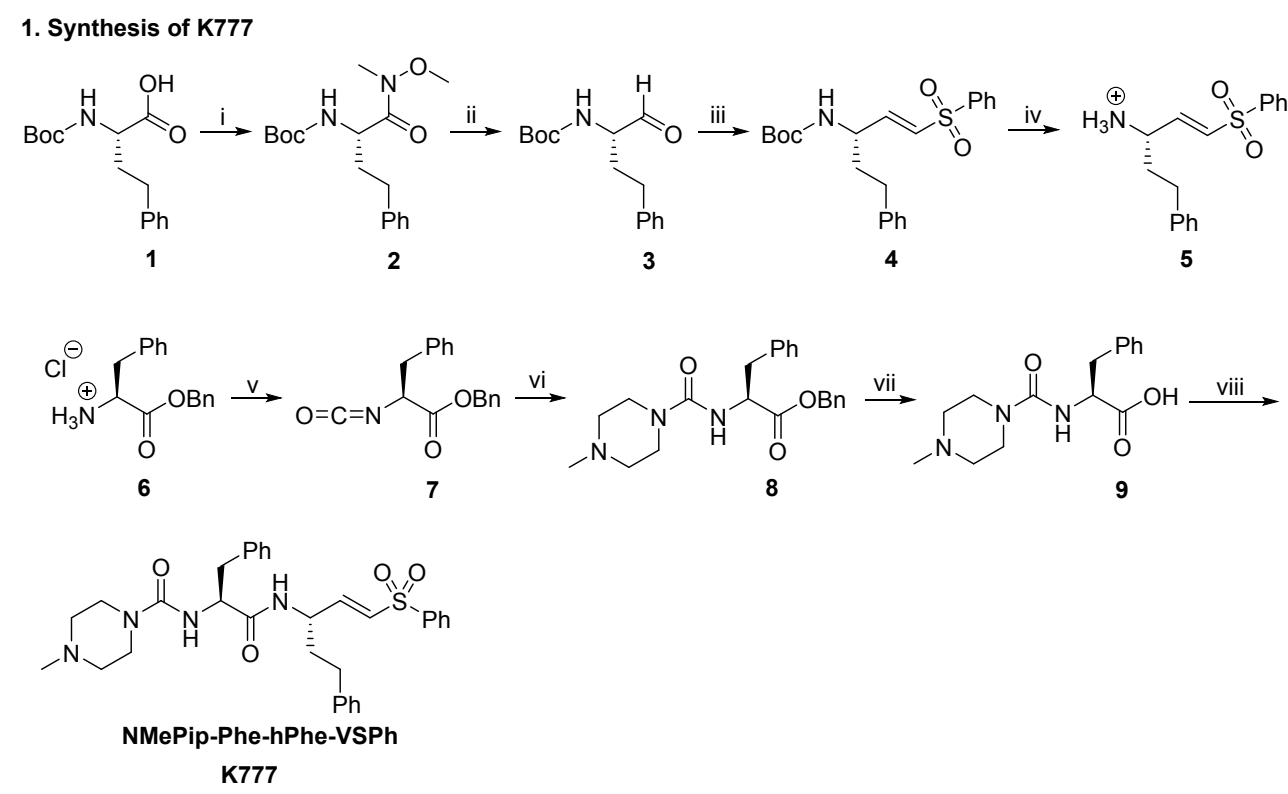

2. Synthesis of Propargyl-K11777
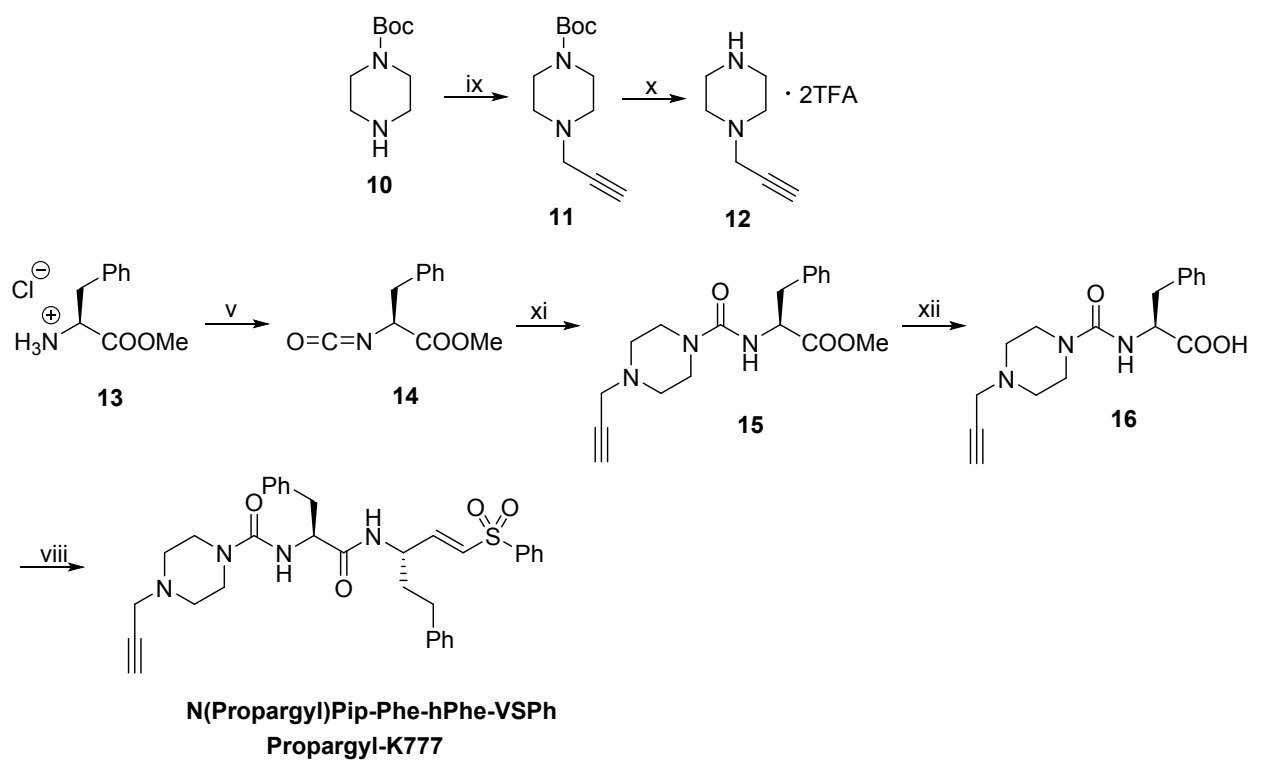

${ }^{a}$ Conditions and reagents: (i) $\mathrm{N}, \mathrm{O}$-dimethylhydroxylamine hydrochloride, T3P, DIPEA, DCM, $0^{\circ} \mathrm{C}, 30 \mathrm{~min}$; (ii) LAH, THF, $-10^{\circ} \mathrm{C}, 30 \mathrm{~min}$; (iii) Diethyl (phenylsulfonyl)methane phosphonate, LHMDS, THF, $-10^{\circ} \mathrm{C}$, 20 min, $0^{\circ} \mathrm{C}, 1 \mathrm{~h}$; (iv) TFA, DCM, $0^{\circ} \mathrm{C}, 3 \mathrm{~h}$; (v) a) $\mathrm{DCM}$, sat. aq. $\mathrm{NaHCO}_{3}$, b) triphosgene, $0{ }^{\circ} \mathrm{C}, 15 \mathrm{~min}$; (vi) 1-Methylpiperazine, THF, DIPEA, $0^{\circ} \mathrm{C}, 10 \mathrm{~min}, 25^{\circ} \mathrm{C}, 16 \mathrm{~h}$; (vii) $10 \% \mathrm{Pd} / \mathrm{C}, \mathrm{MeOH}, 25^{\circ} \mathrm{C}, 20 \mathrm{~h}$; (viii) 5, T3P, DIPEA, DCM, $-10{ }^{\circ} \mathrm{C}, 10 \mathrm{~min}, 0^{\circ} \mathrm{C}, 1 \mathrm{~h}$; (ix) propargyl bromide, DIPEA, $\mathrm{CHCl}_{3},-10{ }^{\circ} \mathrm{C}, 30 \mathrm{~min}$, $25^{\circ} \mathrm{C}, 18 \mathrm{~h}$; (x) TFA, DCM, $0{ }^{\circ} \mathrm{C}, 3 \mathrm{~h}, 25^{\circ} \mathrm{C}, 1 \mathrm{~h}$; (xi) 12, THF, DIPEA, $0{ }^{\circ} \mathrm{C}, 1 \mathrm{~h}, 25^{\circ} \mathrm{C}, 16 \mathrm{~h}$; (xii) a) LiOH, THF, $\left.\mathrm{H}_{2} \mathrm{O}, 0^{\circ} \mathrm{C}, 6 \mathrm{~h}, \mathrm{~b}\right) 4 \mathrm{~N} \mathrm{HCl}$ in dioxane to $\mathrm{pH} 2$. 
Synthesis of K777: Boc-protected L-homophenylalanine 1 was purchased from a commercial source, converted to a Weinreb amide by T3P-catalyzed coupling to $N, O$-dimethylhydroxylamine hydrochloride to afford 2. Reduction of the Weinreb amide 2 using $\mathrm{LAH}$ at $-10{ }^{\circ} \mathrm{C}$ in anhydrous THF provided the Boc-Lhomophenylalanine aldehyde 3. Horner-Wadsworth-Emmons reaction of the aldehyde $\mathbf{3}$ with the commercially available diethyl (phenylsulfonyl)methane phosphonate yielded the vinyl phenyl sulfone 4 .

L-Phenylalanine benzyl ester hydrochloride 6 was reacted with triphosgene to give isocyanate 7, which was further reacted with 1-methylpiperazine to give NMe-Pip-Phe-OBn 8. NMe-Pip-Phe-OBn was subjected to debenzylation using $10 \% \mathrm{Pd} / \mathrm{C}$ with $\mathrm{H}_{2}$ gas to give NMe-Pip-Phe-OH 9. TFA Deprotection of the Boc group of the vinyl phenyl sulfone 4 gave the TFA salt $\mathbf{5}$. The T3P-catalyzed coupling of 5 with NMe-Pip-Phe-OH 9 gave the required compound K777.

Synthesis of K777 alkyne: ${ }^{5}$ Commercially-available t-butyl piperazine-1-carboxylate (1-N-Bocpiperazine) 10 was reacted with propargyl bromide to give 1-N-Boc-propargyl-piperazine 11, which was further treated with TFA to give 1-N-propargyl-piperazine TFA salt 12. L-phenylalanine methyl ester hydrochloride was reacted with triphosgene to give isocyanate 14, which was further reacted with 12 to give N-propargyl-Pip-Phe-OMe 15. The compound 15 was subjected to $\mathrm{LiOH}$ hydrolysis to give Npropargyl-Pip-Phe-OH 16. T3P-catalyzed coupling of $\mathbf{5}$ with acid $\mathbf{1 6}$ gave the required compound K777 alkyne.

\section{4-methyl-N-((S)-1-oxo-3-phenyl-1-(((S,E)-5-phenyl-1-(phenylsulfonyl)pent-1-en-3-yl)amino)propan-} 2-yl)piperazine-1-carboxamide (K777, NMePip-Phe-hPhe-VSPh). To a suspension of TFA salt 5 (0.100 $\mathrm{g}, 0.240 \mathrm{mmol})$ in DCM $(5 \mathrm{~mL})$ at $-10^{\circ} \mathrm{C}$, was added dropwise DIPEA $(0.48 \mathrm{~mL}, 2.744 \mathrm{mmol})$, followed by addition of the acid $9(0.100 \mathrm{~g}, 0.343 \mathrm{mmol})$ and dropwise addition of T3P $(0.33 \mathrm{~mL}, 0.515 \mathrm{mmol})$. The reaction was continued at the same temperature for $10 \mathrm{~min}$ and $0^{\circ} \mathrm{C}$ for $1 \mathrm{~h}$. Upon the completion of the reaction as revealed by TLC analysis $(\mathrm{MeOH} / \mathrm{DCM}=1: 10, \mathrm{v} / \mathrm{v})$, the reaction mixture was diluted with $\operatorname{DCM}(50 \mathrm{~mL})$, and then washed with sat. aq. $\mathrm{NaHCO}_{3}(1 \mathrm{X}), \mathrm{H}_{2} \mathrm{O}(3 \mathrm{X})$ and brine $(1 \mathrm{X})$. The organic layer was dried over anh. $\mathrm{Na}_{2} \mathrm{SO}_{4}$ and filtered. The filtrate was concentrated in vacuo to afford the crude product, which was purified by silica gel column chromatography using a gradient of $1 \%-10 \%$ of MeOH in DCM as eluent to yield the pure product 4-methyl-N-((S)-1-oxo-3-phenyl-1-(( $S, E)-5$-phenyl-1(phenylsulfonyl)pent-1-en-3-yl)amino)propan-2-yl)piperazine-1-carboxamide (K777, NMePip-Phe-hPheVSPh, White solid, $0.089 \mathrm{~g}, 0.155 \mathrm{mmol}, 45 \%$ yield). ${ }^{1} \mathrm{H}$ NMR (400 MHz, $\left.\mathrm{CDCl}_{3}\right) \delta 1.62-1.87$ (m, 2H), $2.22(\mathrm{~s}, 3 \mathrm{H}), 2.23-2.29(\mathrm{~m}, 4 \mathrm{H}), 2.42-2.57(\mathrm{~m}, 2 \mathrm{H}), 2.94-3.05(\mathrm{~m}, 2 \mathrm{H}), 3.22-3.35(\mathrm{~m}, 4 \mathrm{H}), 4.52-$ $4.68(\mathrm{~m}, 2 \mathrm{H}), 5.26(\mathrm{~d}, 1 \mathrm{H}, J=7.8 \mathrm{~Hz}), 6.12\left(\mathrm{dd}, 1 \mathrm{H}, J_{l}=1.5 \mathrm{~Hz}, J_{2}=15.1 \mathrm{~Hz}\right), 6.78\left(\mathrm{dd}, 1 \mathrm{H}, J_{1}=5.0 \mathrm{~Hz}\right.$, $\left.J_{2}=15.1 \mathrm{~Hz}\right), 6.98(\mathrm{~d}, 2 \mathrm{H}, J=7.0 \mathrm{~Hz}), 7.06-7.30(\mathrm{~m}, 9 \mathrm{H}), 7.51(\mathrm{t}, 2 \mathrm{H}, J=7.6 \mathrm{~Hz}), 7.57-7.63(\mathrm{~m}, 1 \mathrm{H})$, 
7.78 - $7.86(\mathrm{~m}, 2 \mathrm{H}) ;{ }^{13} \mathrm{C} \mathrm{NMR}\left(100 \mathrm{MHz}, \mathrm{CDCl}_{3}\right) \delta 31.8,35.7,38.9,43.8,46.0,49.1,54.5,56.0,126.2$, $127.1,127.6,128.4,128.5,128.6,129.3,129.4,130.5$, 133.5, 136.7, 140.4, 140.5, 145.9, 157.0, 172.1; LCMS $m / z$ 575.35, $576.38[\mathrm{M}+\mathrm{H}]^{+},\left(\mathrm{C}_{32} \mathrm{H}_{38} \mathrm{~N}_{4} \mathrm{O}_{4} \mathrm{~S}^{+}\right.$Calcd 575.27); $t_{\mathrm{R}}=3.22 \mathrm{~min}$.

\section{N-((S)-1-oxo-3-phenyl-1-(((S,E)-5-phenyl-1-(phenylsulfonyl)pent-1-en-3-yl)amino)propan-2-yl)-4-} (prop-2-yn-1-yl)piperazine-1-carboxamide (K777 alkyne, N(Propargyl)Pip-Phe-hPhe-VSPh). Followed the procedure from synthesis of K777, using TFA salt 5 (1.513 g, $3.640 \mathrm{mmol})$, DCM (60 mL), acid $16(1.915 \mathrm{~g}, 6.072 \mathrm{mmol})$, DIPEA $(8.50 \mathrm{~mL}, 49 \mathrm{mmol})$ and T3P (5.80 mL, $9.1 \mathrm{mmol})$. White solid, $1.553 \mathrm{~g}, 2.594 \mathrm{mmol}, 71 \%$ yield. ${ }^{1} \mathrm{H}$ NMR $\left(400 \mathrm{MHz}, \mathrm{CDCl}_{3}\right) \delta 1.59-1.87(\mathrm{~m}, 2 \mathrm{H}), 2.21(\mathrm{t}, 1 \mathrm{H}, J=2.4$ $\mathrm{Hz}), 2.36-2.57(\mathrm{~m}, 6 \mathrm{H}), 2.95-3.04(\mathrm{~m}, 2 \mathrm{H}), 3.22-3.37(\mathrm{~m}, 6 \mathrm{H}), 4.53-4.66(\mathrm{~m}, 2 \mathrm{H}), 5.25(\mathrm{~d}, 1 \mathrm{H}, J=$ $7.7 \mathrm{~Hz}), 6.11\left(\mathrm{dd}, 1 \mathrm{H}, J_{1}=1.5 \mathrm{~Hz}, J_{2}=15.1 \mathrm{~Hz}\right), 6.78\left(\mathrm{dd}, 1 \mathrm{H}, J_{1}=5.0 \mathrm{~Hz}, J_{2}=15.1 \mathrm{~Hz}\right), 6.96-7.03(\mathrm{~m}$, 2H), $7.07-7.23(\mathrm{~m}, 9 \mathrm{H}), 7.46-7.56(\mathrm{~m}, 2 \mathrm{H}), 7.57-7.63(\mathrm{~m}, 1 \mathrm{H}), 7.79-7.87(\mathrm{~m}, 2 \mathrm{H}) ;{ }^{13} \mathrm{C}$ NMR $(100$ $\left.\mathrm{MHz}_{\mathrm{CDCl}}\right) \delta 31.8,35.7,38.7,43.7,46.8,49.1,51.2,55.9,73.6,78.2,126.2,127.1,127.6,128.4,128.5$, 128.6, 129.3 (2C), 130.5, 133.4, 136.7, 140.3, 140.5, 145.8, 156.9, 172.0; LC-MS m/z 599.25, 600.28 $[\mathrm{M}+\mathrm{H}]^{+},\left(\mathrm{C}_{34} \mathrm{H}_{38} \mathrm{~N}_{4} \mathrm{O}_{4} \mathrm{~S}^{+}\right.$Calcd 599.27); $t_{\mathrm{R}}=3.68 \mathrm{~min}$.

\section{ABBREVIATIONS USED}

DIPEA, $N, N$-Diisopropylethylamine; hPhe, homophenylalanine; LAH, lithium aluminum hydride; LHMDS, lithium bis(trimethylsilyl)amide; NMePip, N-methylpiperazinyl; T3P, propylphosphonic anhydride; TFA, trifluoroacetic acid; VSPh, vinyl sulfone phenyl. 
HPLC trace and and MS of $A b z-S A V L Q S G F R K(D N P)-N_{2}$
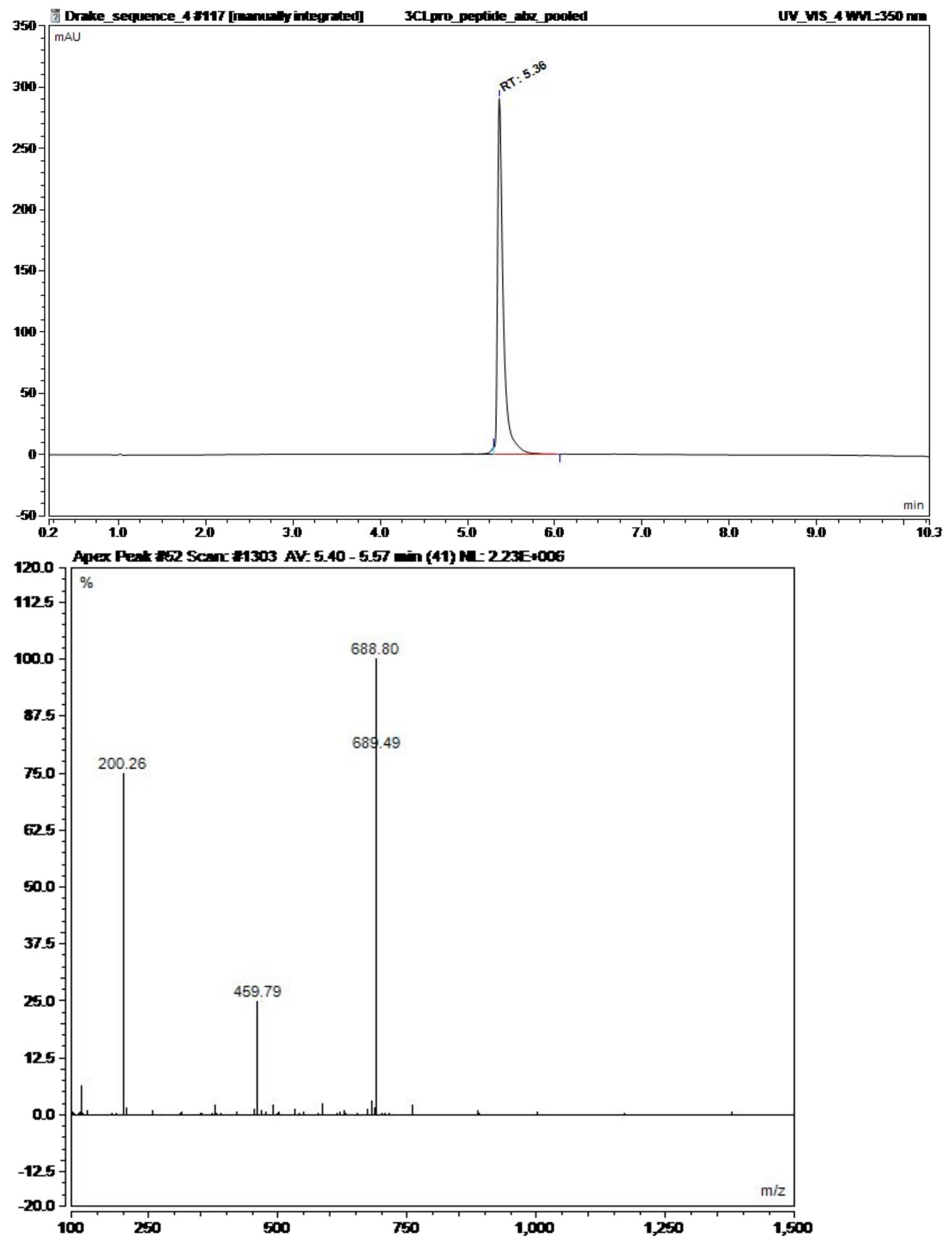
HPLC Trace of K777 (NMePip-Phe-hPhe-VSPh)

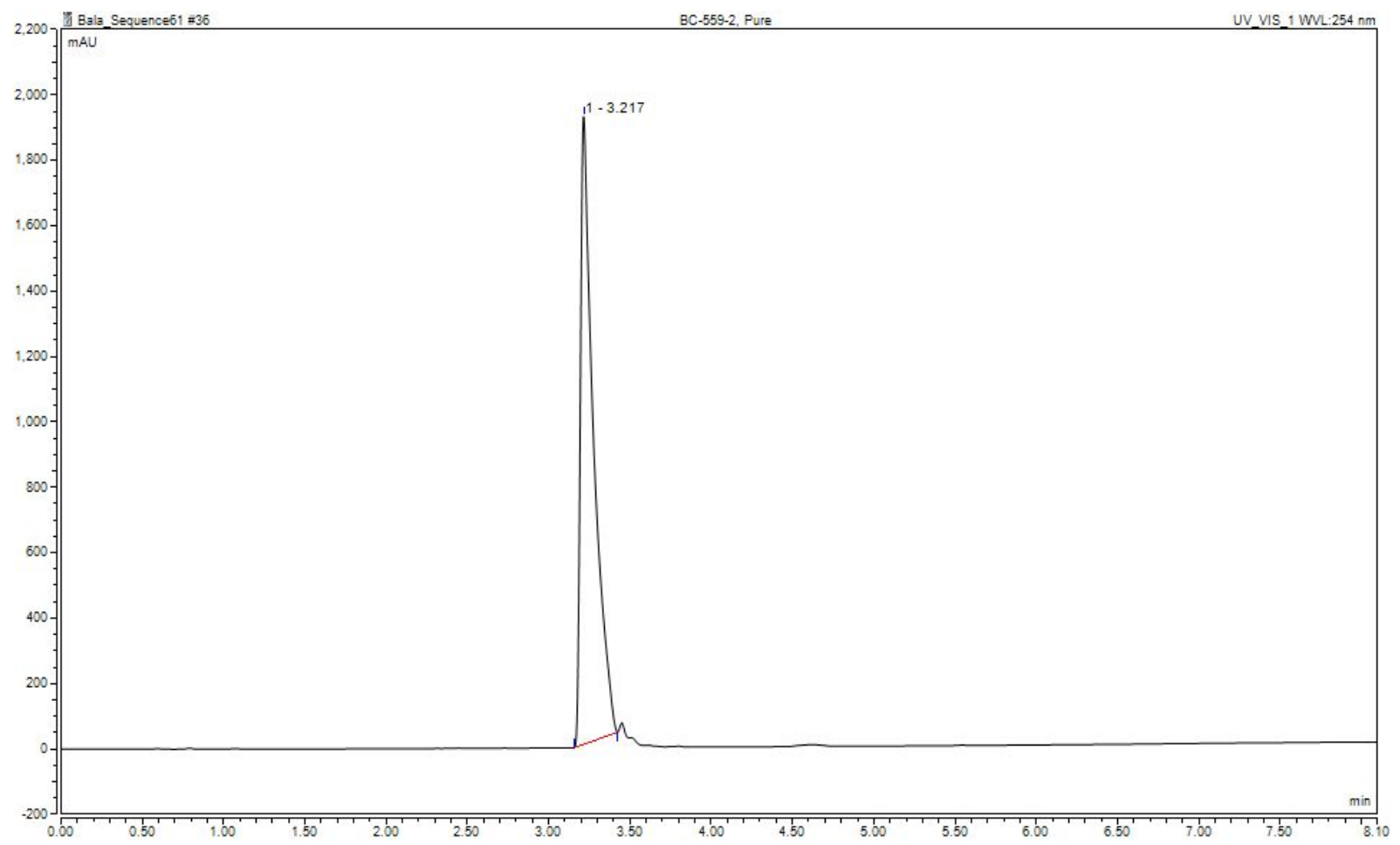

HPLC Trace of K777 alkyne (N(Propargyl)Pip-Phe-hPhe-VSPh)

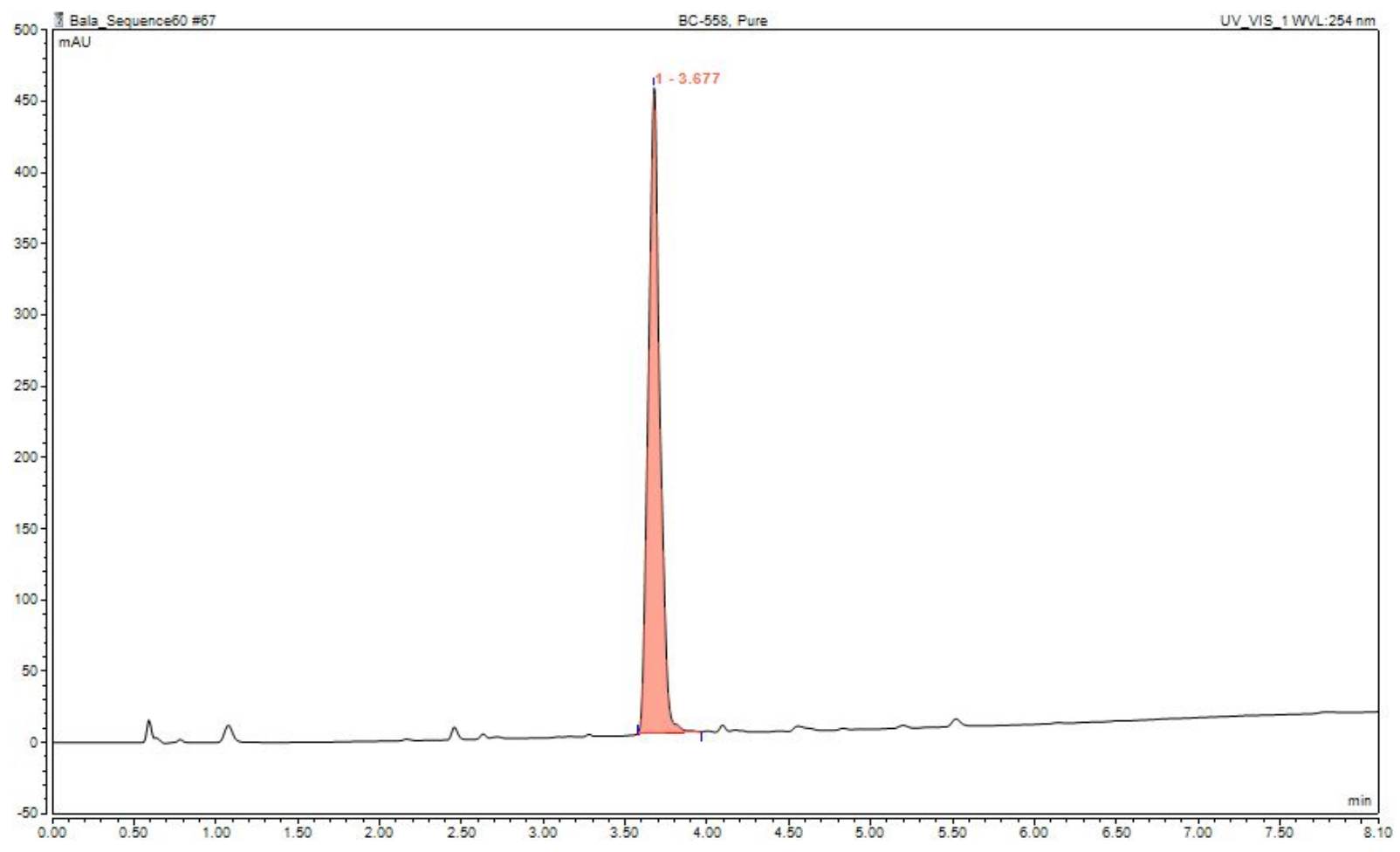


${ }^{1} \mathrm{H}$ NMR spectrum of K777 (NMePip-Phe-hPhe-VSPh)

BC-559-2, 1 H NMR, Purified, CDCl3
PROTON_TAMU CDCl3 / data bala 14

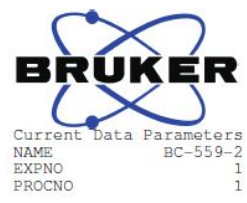

30

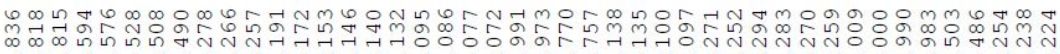

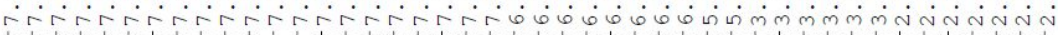
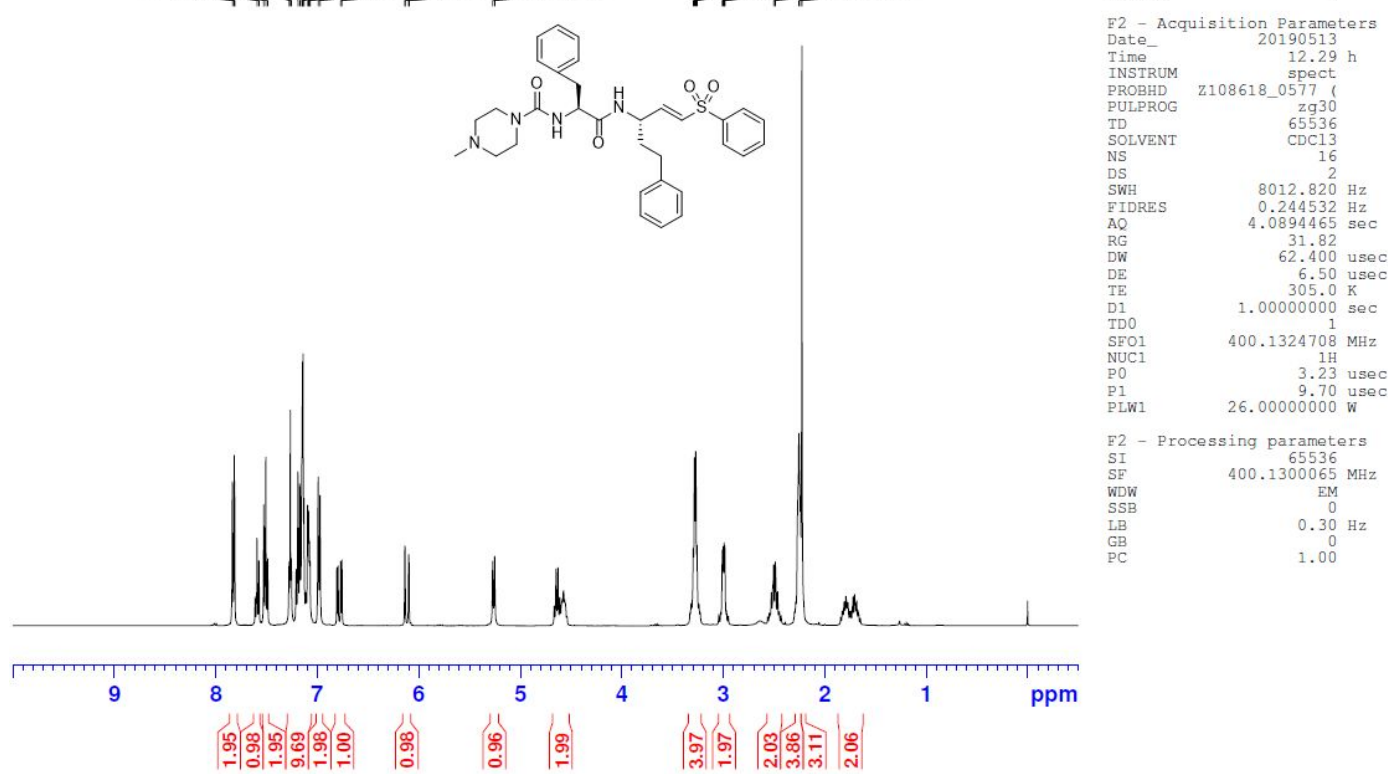

${ }^{13}$ C NMR spectrum of K777 (NMePip-Phe-hPhe-VSPh)
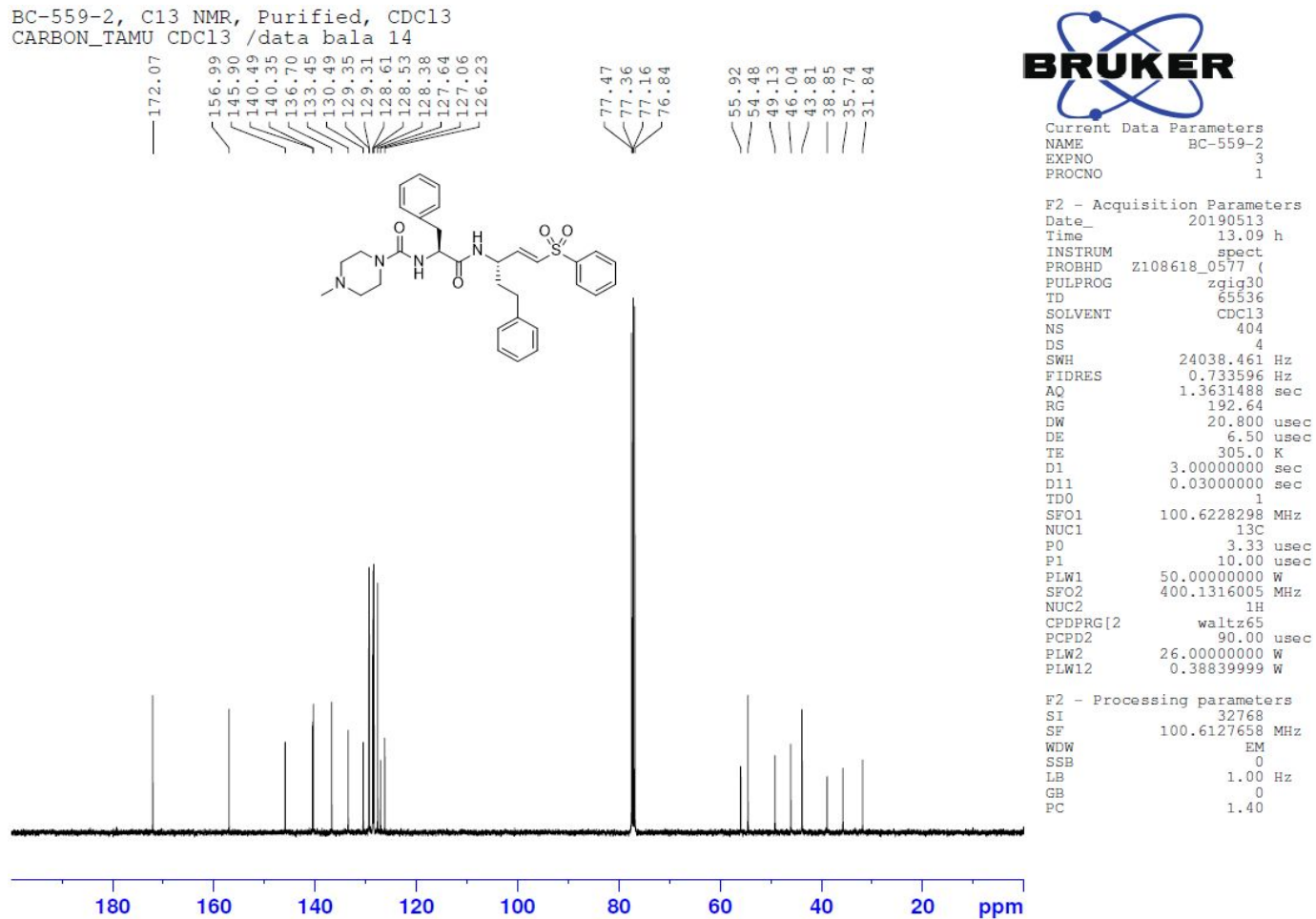
${ }^{1} \mathrm{H}$ NMR spectrum of K777 alkyne (N(Propargyl)Pip-Phe-hPhe-VSPh)

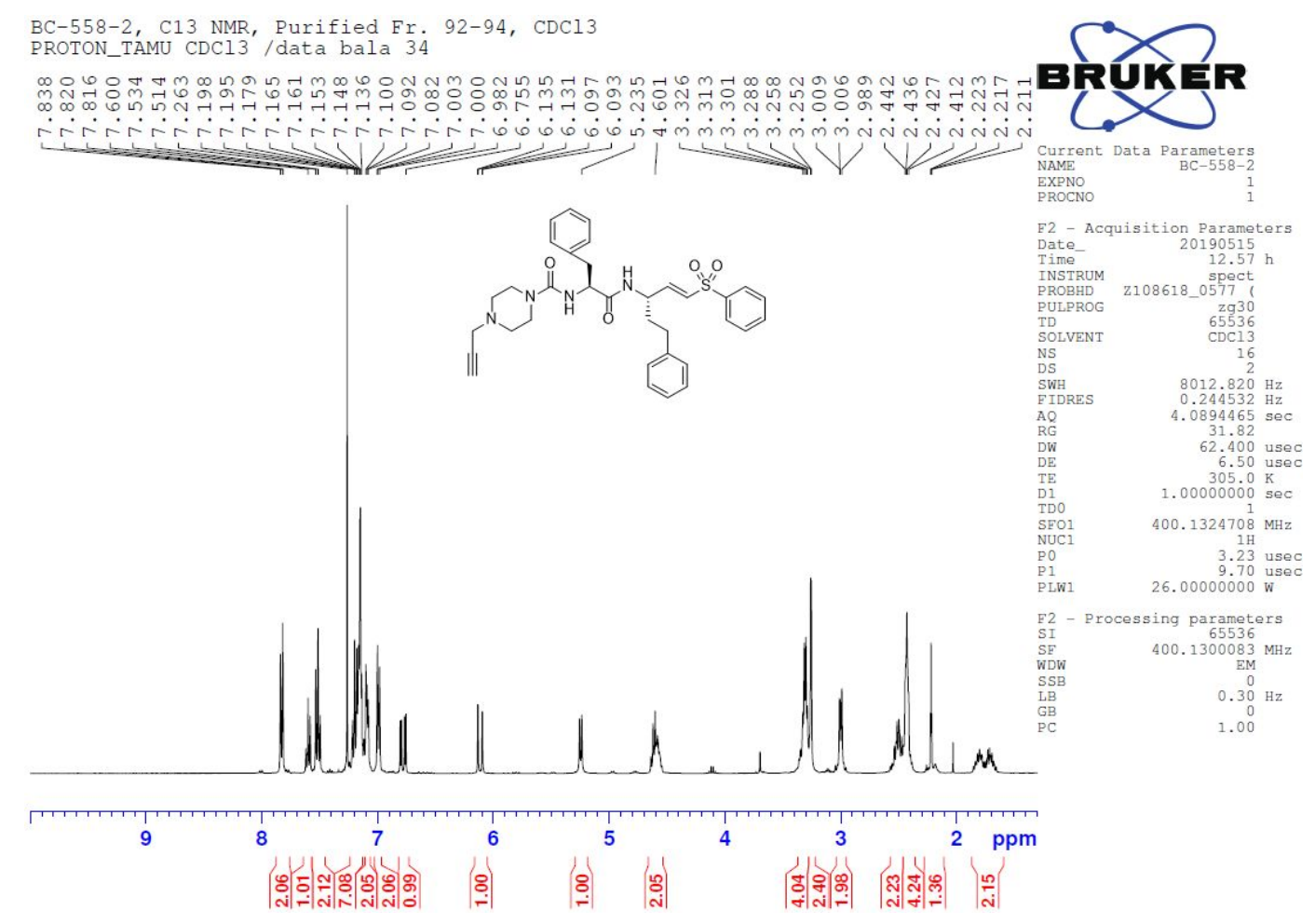

${ }^{13} \mathrm{C}$ NMR spectrum of K777 alkyne (N(Propargyl)Pip-Phe-hPhe-VSPh)

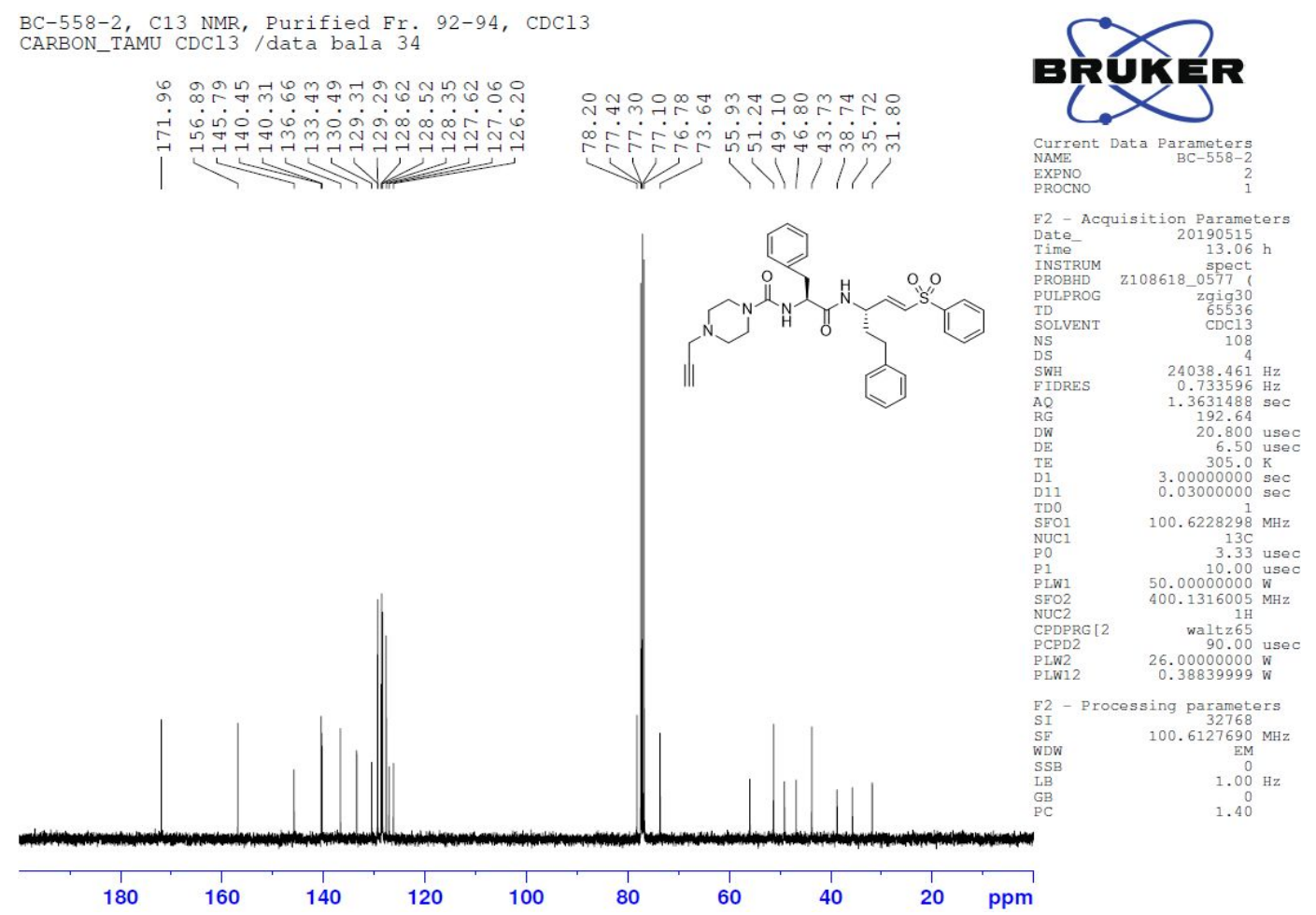




\section{References:}

[1] C. D. Owen, C. D., Lukacik, P., Strain-Damerell, C. M., Douangamath, A., Powell, A. J., Fearon, D., Brandao-Neto, J., Crawshaw, A. D., Aragao, D., Williams, M., Flaig, R., Hall, D. R., McAuley, K. E., Mazzorana, M., Stuart, D. I., Delft, F. v., and Walsh, M. A. (2020) 6Y84, SARS-CoV-2 main protease with unliganded active site (2019-nCoV, coronavirus disease 2019, COVID-19), RCSB Protein Data Bank, RCSB Protein Data Bank.

[2] Chen, L., Liu, W., Zhang, Q., Xu, K., Ye, G., Wu, W., Sun, Z., Liu, F., Wu, K., Zhong, B., Mei, Y., Zhang, W., Chen, Y., Li, Y., Shi, M., Lan, K., and Liu, Y. (2020) RNA based mNGS approach identifies a novel human coronavirus from two individual pneumonia cases in 2019 Wuhan outbreak, Emerging Microbes \& Infections 9, 313-319.

[3] Zhang, L., Lin, D., Sun, X., Curth, U., Drosten, C., Sauerhering, L., Becker, S., Rox, K., and Hilgenfeld, R. (2020) Crystal structure of SARS-CoV-2 main protease provides a basis for design of improved $\alpha$-ketoamide inhibitors, Science 368, 409.

[4] Xue, X., Yang, H., Shen, W., Zhao, Q., Li, J., Yang, K., Chen, C., Jin, Y., Bartlam, M., and Rao, Z. (2007) Production of authentic SARS-CoV M(pro) with enhanced activity: application as a novel tag-cleavage endopeptidase for protein overproduction, Journal of molecular biology 366, 965975.

[5] Yang, P.-Y., Wang, M., He, C. Y., and Yao, S. Q. (2012) Proteomic profiling and potential cellular target identification of K11777, a clinical cysteine protease inhibitor, in Trypanosoma brucei, Chemical Communications 48, 835-837.

[6] Schneider, C. A., Rasband, W. S., and Eliceiri, K. W. (2012) NIH Image to ImageJ: 25 years of image analysis, Nature Methods 9, 671-675. 